\title{
Discussion
}

\section{Temporal aspects of genetic stratigraphic units in continental sedimentary basins: Examples from the Ebro basin, Spain}

\author{
Francisco Javier Pérez-Rivarés ${ }^{\mathrm{a},}$, Concha Arenas ${ }^{\mathrm{a}}$, Gonzalo Pardo ${ }^{\mathrm{a}}$, Miguel Garcés ${ }^{\mathrm{b}}$ \\ a Division of Stratigraphy, Department of Earth Sciences, University of Zaragoza, Calle Pedro Cerbuna 12, 50009 Zaragoza, Spain \\ ${ }^{\mathrm{b}}$ Department of Earth and Ocean Dynamics, University of Barcelona, Campus de Pedralbes, 08028 Barcelona, Spain
}

\section{A R T I C LE INFO}

\section{Keywords:}

Continental sedimentary basins

Genetic stratigraphy

Tecto-sedimentary analysis

Magnetostratigraphy

Conformable boundaries

Degree of diachroneity

\begin{abstract}
A B S T R A C T
The utility of genetic stratigraphy lies with the fundamental relationship between genetic stratigraphic units and correlative intervals of geologic time. While high-resolution studies may reveal varying degrees of diachroneity that are associated with their bounding surfaces, genetic stratigraphic units are generally viewed as chronostratigraphic in nature, representing specific periods of basin fill. Despite the vast literature on basin analysis, an evaluation of the temporal character of the boundaries between genetic stratigraphic units, particularly in cases where they are conformable, has not yet been undertaken. The Cenozoic Ebro basin is a foreland basin on the north-eastern Iberian Peninsula that provides a case for assessing the temporal character of the boundaries between genetic stratigraphic units. These units are termed "tecto-sedimentary units", following the method of tecto-sedimentary analysis that is used in some continental basins. In the Ebro basin tecto-sedimentary analysis is based on direct field observations. In this work, magnetostratigraphic data from four tecto-sedimentary units (units T4 to T7) that span rocks of lower and middle Miocene age (ca. 1000 m thick) in the central and western areas of the basin are analysed. The study area contains alluvial, fluvial and lacustrine deposits that were sourced from Pyrenean and Iberian areas, whose catchments were structured during the collision of Iberia and Eurasia. New magnetostratigraphic data from this study and previously published magnetostratigraphic data enable us to determine the ages of these tecto-sedimentary unit boundaries throughout a $200-\mathrm{km}$-long, east-west transect that extends from the basin centre to the southwestern margin. The results indicate that the diachrony of the three boundaries between the Miocene tecto-sedimentary units through the central Ebro basin is less than $0.3 \mathrm{Ma}$ where they are conformable. This low degree of diachroneity may be attributed to the effects of allogenic, largely tectonic processes that operate in the catchment areas and methodological inaccuracies. These results provide empirical support to the idea that genetic stratigraphic units are bounded by surfaces that exhibit low amounts of diachroneity where they are conformities.
\end{abstract}

\section{Introduction}

Basin analysis involves the division of basin-filling rocks into genetic stratigraphic units. Genetic stratigraphic units (cf., Embry, 2009) are important to study basin history because they are generally viewed as representative of specific periods of geologic time, irrespective of lithology. Such units are bound by key strati- graphic surfaces (e.g., sequence boundaries, maximum flooding surfaces) depending on the model that is employed (see Mitchum et al., 1977; Johnson and Murphy, 1984; Van Wagoner et al., 1987; Galloway, 1989; and Embry, 2009; Catuneanu et al., 2009, 2011 for a full discussion). In Spain, basin analysis with genetic stratigraphic units began with the with "tecto-sedimentary analysis" (TSA), which was used by Garrido-Megías (1973) to study Mesozoic

\footnotetext{
* Corresponding author.

Email address: perezrivares@gmail.com (F.J. Pérez-Rivarés)
} 
and Cenozoic rocks in the South Pyrenean basin, and by Garrido and Villena (1977) to study the Germanic Triassic. TSA is based on the early work of Delfaud $(1972,1974)$, and its theoretical concepts were refined by Megías (1982).

Genetic stratigraphic units that were recognised via TSA were termed by Megías (1982) 'tecto-sedimentary units' (TSUs). Conceptually, a TSU is a three-dimensional body of sedimentary rocks that has a definite vertical trend, either fining or coarsening upward, and is bounded by regional unconformities and their correlative conformities. At the scale of the resolution of dating methods, the boundaries between TSUs should represent synchronous geologic timelines where they are conformable (Megías, 1982). Thus, each TSU that is characterised in a basin has chronostratigraphic significance, and successive TSUs do not overlap in time. In this respect, a TSU is partially equivalent to a depositional sequence that is established by seismic stratigraphy (Mitchum et al., 1977; Vail, 1987), as stated by Pardo et al. (1989), although the methods and data that are used in each case (i.e., direct field observations versus seismic interpretation) and the dominant allogenic controls at play may vary.

An early application of TSA was the study of Neogene marine, oil-bearing rocks in the western Mediterranean (Soler et al., 1986; Martínez del Olmo et al., 1986). In these works seismic profiles, continuous drilling cores and well-logs were used and compared with information from inland outcrops. The authors defined seven TSUs that were regressive in evolution and formed in relation to the Betic thrust that stacked in the Balearic Islands and synchronous extension in the western basin margin.

Despite the active development of sequence stratigraphy as a research topic by the late 1980s (see Bally, 1987; Wilgus et al., 1988), this theme did not greatly contribute to the analysis of continental basins, particularly basins whose evolution had no relation to sea-level changes. This case applies to most Neogene continental basins in the Iberian Peninsula, the stratigraphic studies of which have relied mostly on the outcropping record. Available core data, well logs and/or seismic profiles are rare, disperse and sometimes of insufficient quality. González et al. (1988) and Pardo et al. (1989) precisely defined the types and meaning of TSU boundaries in continental basins, compared TSA and sequence stratigraphy concepts, and used TSUs as a correlation tool in large continental basins with disconnected outcrops. Most scientists had accepted by the mid-1990s that factors other than sea-level changes, including climate change and regional tectonism, may play a key role in changes in accommodation, and hence in sequence architecture (Miall, 1995, 2010, 2016). A few works focused on sequence stratigraphy in continental basins (Catuneanu and Elango, 2001; Fanti and Catuneanu, 2010). After González et al. (1988) and Pardo et al. (1989), TSA was more extensively applied through the study of fully continental (endorheic) Cenozoic basins in Spain, such as the intermontane Ebro, Duero and Tagus basins and some intramontane continental basins in the Betic and Iberian Ranges (Mediavilla and Dabrio, 1988; Pérez, 1989; González, 1989; Alonso-Zarza et al., 1990; Viseras, 1991; Santisteban et al., 1991; Santisteban et al., 1996a; Santisteban et al., 1996b; Muñoz, 1992; Arenas, 1993; Villena et al., 1996a; Villena et al., 1996b; Mediavilla et al., 1996; Muñoz-Jiménez and Casas-Sainz, 1997; Luzón, 2001; López Olmedo et al., 2004; Pla et al., 2007; Ezquerro, 2017).

These basins were isolated from marine influence, so the primary allogenic control during filling was mainly tectonic activity in the basins' bounding mountain ranges. This tectonic activity consisted of thrusting and uplift 1) in the Pyrenees and Iberian Ranges for the Ebro basin (Muñoz-Jiménez and Casas-Sainz, 1997; Arenas et al., 2001), 2) in the Central System and Altomira Sierra for the Tagus basin (Calvo et al., 1989), and 3) in the Cantabrian and Iber- ian Ranges for the Duero basin (Mediavilla et al., 1996). An extensive tectonic regime occurred in the eastern Iberian Range, as with the Teruel basin (Ezquerro, 2017). In all these examples, the tectonic activity at the bounding ranges, alongside climate evolution, controlled the sediment supply and basin accommodation and produced sedimentary sequences that reflect the prograding or retrograding evolution of the related fluvial systems and the retraction or expansion evolution of the related lacustrine systems.

In the above-mentioned works, the correlation of TSUs throughout every basin was based on outcrop stratigraphic criteria and similarities between vertical sedimentary trends. However, these correlations may be imperfect, and the identification of key surfaces such as TSU boundaries may not be highly accurate, particularly in sequences that correspond to distal alluvial or lacustrine settings. Therefore, evaluating the temporal character of TSU boundaries requires a more accurate dating method to facilitate age correlation. In continental basins, magnetostratigraphy has proven to be one of the most suitable tools for this purpose (c.f., Krijgsman et al., 1996; Garcés et al., 2001; Pérez-Rivarés et al., 2002, 2004), although few published studies have been devoted to this goal. Relative to this subject, three Miocene genetic stratigraphic units have been defined and correlated throughout the Madrid basin in the central Iberian Peninsula (see Antunes et al., 1987; Alonso-Zarza et al., 1990; Calvo et al., 1989; López Olmedo et al., 2004). These units, which were termed lower, intermediate and upper, were first dated as Miocene based on their macro- and micro-mammal fossil contents. Montes et al. (2006) performed a magnetostratigraphic analysis of the lower and intermediate units in the central sector of the Madrid basin and established the age of the boundary between these two units to be 14.4Ma. However, Abels et al. (2010) estimated the age of the same boundary in the north-eastern sector of the same basin to be $15.6 \mathrm{Ma}$, and concluded that this boundary is diachronous because the different sectors of the basin evolved separately.

In the Ebro basin, eight TSUs (T1 to T8) that range in age from Thanetian to the middle Miocene have been identified based solely on measured stratigraphic sections (Villena et al., 1996a; Muñoz et al., 2002; Pardo et al., 2004). Several magnetostratigraphic studies that span the Miocene series have been conducted in the central (Pérez-Rivarés et al., 2002, 2004; Larrasoaña et al., 2006) and northern (Oliva-Urcia et al., 2016) sectors of the Ebro basin. This work attempts to build upon these previous works with new magnetostratigraphic data from the central and western areas of the Ebro basin. The combined datasets represent the Miocene record across a large extent of the basin and thus provide an excellent opportunity to analyse the temporal character of the genetic stratigraphic unit boundaries that have been established by the TSA methodology. This work focuses on a $200-\mathrm{km}$-long east-west transect that extends from the basin centre to its southwestern margin and compares the results to previously published data from the northern basin's margin.

\section{Methods}

\subsection{Tecto-sedimentary analysis (TSA)}

TSA is a method of basin analysis that was first developed during the early 1970s (Garrido-Megías, 1973) to study a portion of the South Pyrenean foreland basins. The active tectonic context in which the basin evolved involves the use of the prefix "tecto" in the nomenclature of units and methodology. The basis of TSA is the division of a sedimentary basin's fill into successions of strata that are characterised by a definite vertical sedimentary trend (Fig. 1). Each of these rock successions was deposited "during a specific in- 


\section{STRATIGRAPHIC CROSS SECTION}

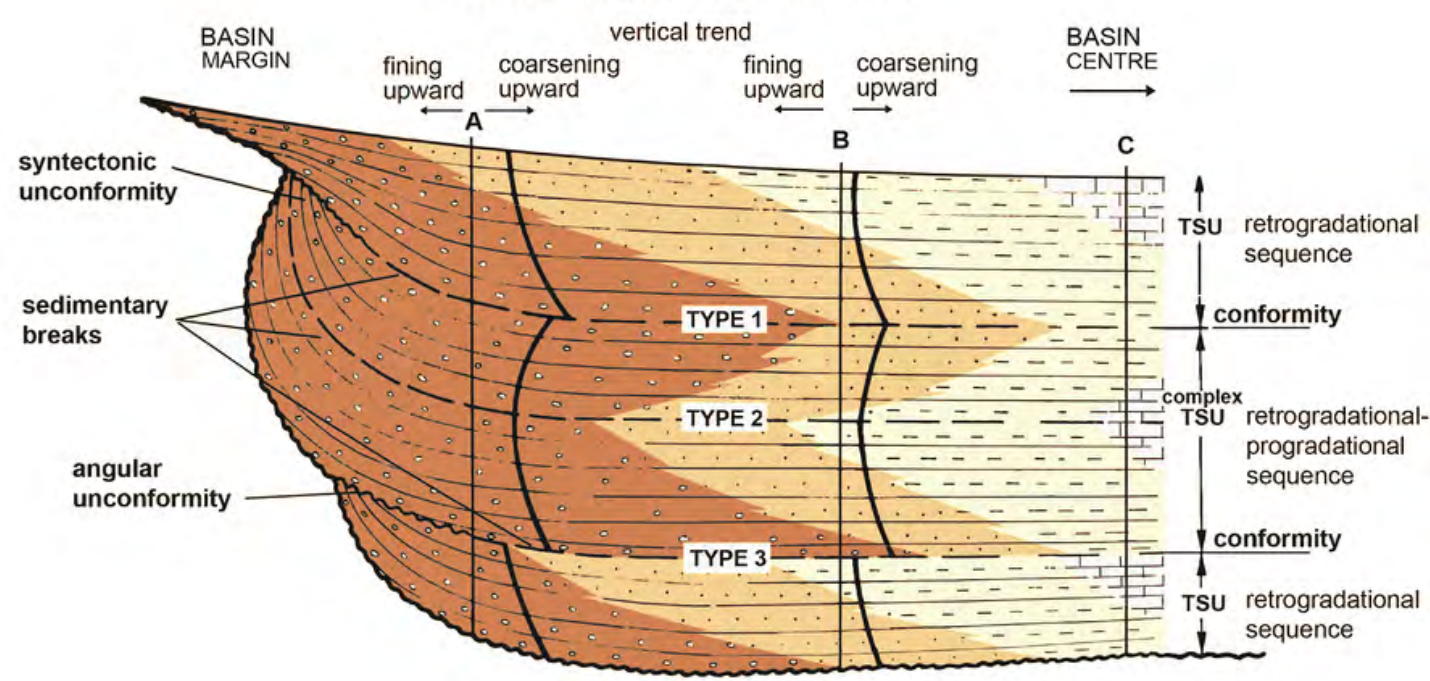

CHRONOSTRATIGRAPHYC CHART

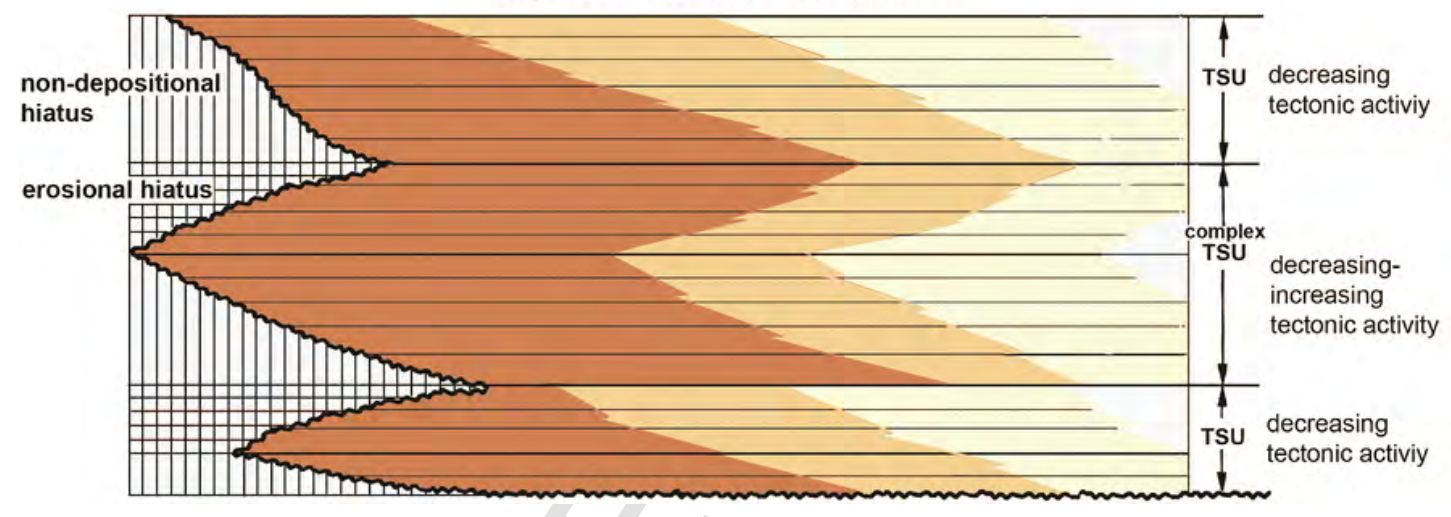

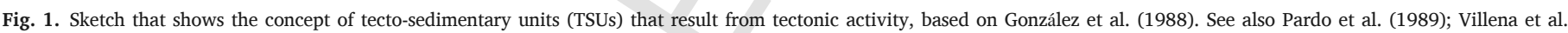

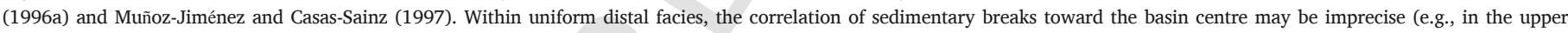

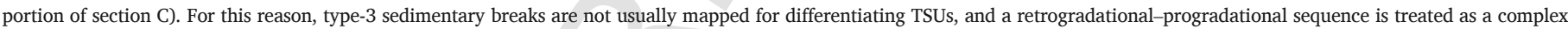
TSU.

terval of geologic time, under a tectonic and sedimentary dynamic of definite polarity" (translated from Megías, 1982). These successions, which are generally hundreds of meters thick, were termed 'tecto-sedimentary units' (TSUs) and the boundaries between TSUs were termed "sedimentary breaks". Sedimentary breaks are surfaces of basinal extent (see González et al., 1988 and Pardo et al., 1989) that separate successions of strata that exhibit either of the following (Fig. 1):

a) different vertical sedimentary trends; the sedimentary break is defined by either a change from coarsening upward to fining upward (type-1 sedimentary break) or a change from fining upward to coarsening upward (type-2 sedimentary break), or

b) similar vertical sedimentary trends that are separated by a sharp shift in grain size or lithology (type-3 sedimentary break).

A type-2 sedimentary break can be difficult to recognize when it occurs within uniform distal facies (e.g., alluvial or lacustrine facies). Thus, this type of break is not commonly used to differentiate TSUs, and such retrogradational-progradational successions are treated as complex TSUs (Fig. 1).

Sedimentary breaks are generated by inflections or sharp changes in the rate or intensity of the allogenic process that con- trolled the basin-fill dynamics (Pardo et al., 1989; Villena et al., 1996a). When the tectonics are the operating allogenic factor, these boundaries are 1) syntectonic or angular unconformities along the basin's margins or zones that are related to active structures within the basin and their correlative basinward conformities (type- 1 or -3 sedimentary breaks, respectively) or 2) conformities throughout the basin (type-2 sedimentary breaks) (González et al., 1988; Fig. 1).

When the climate is the main controlling allogenic factor, the boundaries between the resulting TSUs in fully continental basins are either 1) reversals from coarsening upward to fining upward if the aridity changes from increasing to decreasing or 2) reversals from fining upward to coarsening upward if the aridity changes from decreasing to increasing. These reversals were termed type- 4 and -5 sedimentary breaks, respectively, by Pardo et al. (1989). These breaks are similar to the type- 1 and -2 sedimentary breaks in Fig. 1, respectively, but differ in the following aspects: types 4 and 5 are conformities, or locally paraconformities, throughout the basin and occur within successions of strata with a general onlap geometry at the basin's margins.

Thus, TSA postulates that TSUs are genetically linked to allogenic processes and that the bounding sedimentary breaks form when the intensity or velocity of the allogenic process or a combi- 
nation of several allogenic processes that are relevant to the basin fill reach a maximum or minimum in intensity, in other words, when the process's acceleration is null (Pardo et al., 1989). Therefore, TSUs are genetic stratigraphic units, and every TSU in a basin that formed during a concrete geological time interval cannot coincide with the formation time of other TSUs. Relative to its principles, TSA is similar to other methods of sequence stratigraphy. For example, 1) a type-1 boundary, when a conformity, is similar to a "maximum regressive surface" and a type-2 boundary is similar to a "maximum flooding surface", and 2) TSA would consider each of the system tracts that comprise a depositional sequence to be a simple TSU. However, the use of TSA has been limited in scope because of the late diffusion of its concepts and applications through publication in international scientific journals. Thus, TSA has been used for basin analysis solely in the Iberian Peninsula.

The use of the TSA method requires the following:

- the recognition of unconformities and/or surfaces that represent inflection or changes in the vertical sedimentary trend of local stratigraphic sections in a basin,

- the correlation of such surfaces throughout that basin, with those of greater extent being considered TSU boundaries if they represent the same type of sedimentary break throughout the basin,

- the characterisation of each TSU by means of the vertical sedimentary trend and the establishment of the relative time position within the basin fill,

- TSU mapping through the basin,
- the interpretation of each TSU 1) as a record of allogenic factors that worked at the time of the basin fill and 2) relative to the successive stages of palaeogeographic evolution of the basin.

One of the most difficult issues regarding the use of TSA is the correlation of TSU boundaries through a basin. Preferably, the corresponding surfaces should be traced by means of photogeological methods, e.g., from the basin margin to the basin centre. However, correlation can be even more difficult across the basin centre because changes in the vertical sedimentary trend that define the sedimentary breaks at this location commonly occur within relatively thick, conformable successions of strata that consist of rocks with uniform lithology and texture (Fig. 1). In continental basins, this scenario typically corresponds to distal alluvial, palustrine and lacustrine environments, and sometimes the corresponding record along the basin strike represents deposition from different sedimentary systems.

\subsection{Magnetostratigraphy}

\subsubsection{Sampling}

Three new stratigraphic successions in the Ebro Basin (Ontiñena, or section 1 , in the Sierra de Alcubierre area, and Lugar-Melero and Umbría Alta, or sections 11 and 12, in the Tarazona area) were sampled for magnetostratigraphic analysis (see Fig. 2 for locations). From a sedimentological perspective, the lithologies for the magnetostratigraphic sampling were mainly chosen between distal and lacustrine alluvial environments, where the grain size is fine and the energy conditions are low, which favours the

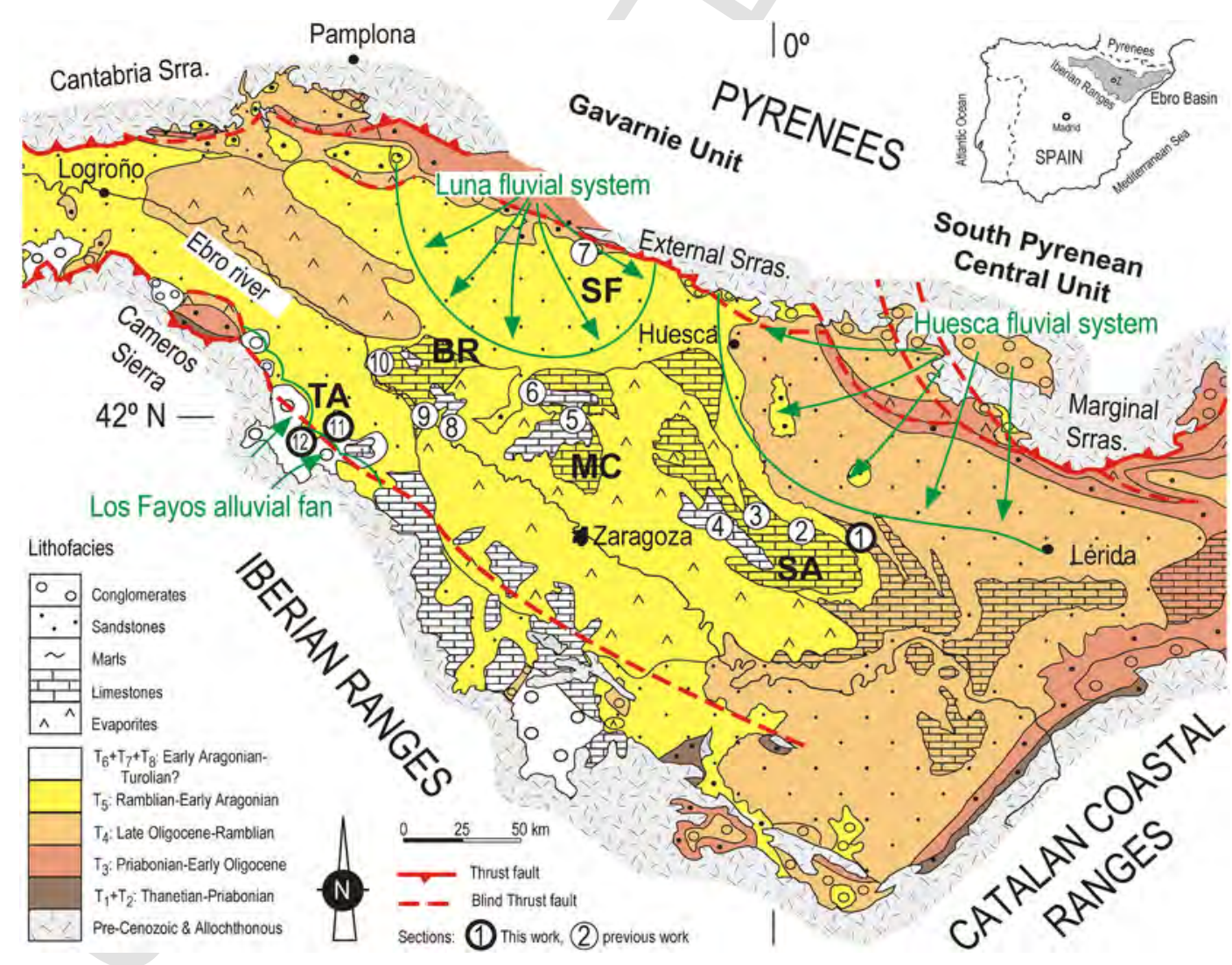

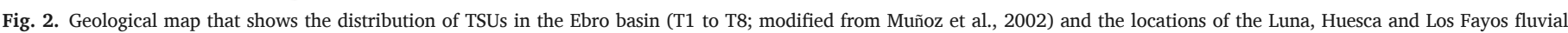

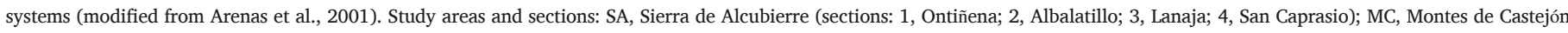

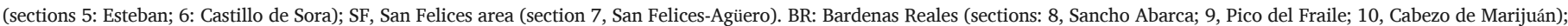
TA: Tarazona area (sections: 11, Lugar-Melero; 12, Umbría Alta). 
quality of the magnetostratigraphic data. The successions mostly consist of reddish, orange and light-brown alluvial and fluvial mudstone and sandstone beds with some interbedded beige to grey lacustrine limestone and marlstone beds. In section 12, brown and reddish sandstones and conglomerates that correspond to proximal alluvial facies are present.

In section 1,120 palaeomagnetic sites were sampled across $142 \mathrm{~m}$ of stratigraphic thickness. In section 11 , which has a stratigraphic thickness of $57 \mathrm{~m}, 52$ palaeomagnetic sites were sampled. In section 12, 116 palaeomagnetic sites were sampled through a 223-m-thick succession. At least two oriented cores (samples) were collected at each palaeomagnetic site with a portable battery-operated drill. The samples were oriented by using a magnetic compass that was coupled to a core-orienting device. When sampling the alluvial facies, the reddish, orange and light-brown mudstones and fine sandstones were cored wherever possible, and coarse-grained lithologies were avoided. When sampling lacustrine facies, marls and limestones were typically cored. The occurrence of suitable lithologies for palaeomagnetic analysis led to a sampling density of 1 site per $1-2 \mathrm{~m}$, with the exception of two intervals in section 12 , where the abundance of conglomerates or the presence of poor-quality exposures limited the sampling density to 1 site per $3-3.5 \mathrm{~m}$.

\subsubsection{Palaeomagnetic procedures}

The palaeomagnetic analyses consisted of stepwise thermal demagnetization and the subsequent measurement of the natural remanent magnetization (NRM) at intervals between $10^{\circ} \mathrm{C}$ and $100^{\circ} \mathrm{C}$, which were conducted at temperatures from room temperature to $680^{\circ} \mathrm{C}$. This procedure was performed on at least one sample per site. The remanent magnetization was measured by using a 755-model superconducting rock magnetometer (2G Enterprises) at the Palaeomagnetic Laboratories of the Universitat de Barcelona (Serveis de Suport a la Reçerca of the University of Barcelona and the Spanish National Research Council, CSIC).

The palaeomagnetic data were analysed with the PALDIR software, which was developed by the Paleomagnetic Laboratory of the University of Utrecht and VPD (Virtual Directions in Paleomagnetism; Ramón et al., 2017). Directional palaeomagnetic components were determined from visual inspection of the vector endpoint demagnetization diagrams (Zijderveld, 1967). The directions of the characteristic remanent magnetization (ChRM) were calculated from the demagnetization diagrams by using principal component analysis (PCA; Kirschvink, 1980). An inversion test was applied to verify the stability of the characteristic signal (McFadden and McElhinny, 1990). Positive and negative latitudes relative to the calculated virtual geomagnetic poles (VGPs) were interpreted, respectively, as normal and reversed polarities. Normal and reversed magnetozones were defined by at least two adjacent palaeomagnetic sites with the same polarity. One-site reversals were denoted as half-bar magnetozones in the local magnetostratigraphic logs but were not considered for magnetostratigraphic correlation purposes.

The calculated ages of the TSU boundaries were obtained by linear interpolation between the ages of the boundaries of the chron in which the TSU boundary was located. Thus, the age of each TSU boundary was estimated at the different areas that were considered in this work.

\subsection{Resolution of the magnetostratigraphic and biostratigraphic data}

Magnetostratigraphy has a $10^{4}$-year time resolution at best, depending on the reversal rate of the geomagnetic field at the time the rocks were deposited (Opdike and Channell, 1996; Kodama and
Hinnov, 2014). In the study area, the usual sampling density that is used is sufficient to achieve a time resolution of $14-28 \mathrm{ka}$ for the minimum rate of accumulation of $7 \mathrm{~cm} / \mathrm{ka}$ (Pérez Rivarés, 2016). This resolution facilitates the confident identification of lower- and middle-Miocene geomagnetic polarity reversals, with chrons of $206 \mathrm{ka}$ in average duration. Only one magnetozone in this study has a duration (23ka) below this time resolution (see Gradstein et al., 2012).

Linear interpolation was used to calculate the age of the studied TSU boundaries; this method has been applied to Miocene chrons with a maximum duration of $300 \mathrm{ka}$, with the average chron duration being $206 \mathrm{ka}$. This calculation assumes that the sedimentation rate was constant. Although this assumption cannot be proven true or false, the results from this approach are currently the best age results that can be obtained from magnetostratigraphic dating.

The chronological scheme that is used as a reference in this work (e.g., in Figs. 8, 9 and 10 below) encompasses the Mammal Neogene Units for Europe (MN units) from Mein (1975), the local biozonation for Spanish Neogene faunas from Daams and Freudenthal (1981), the continental stages Ramblian (Daams et al., 1977) and Aragonian (Daams et al., 1977), and the Geomagnetic Polarity Time Scale (GPTS) from Gradstein et al. (2012). Biostratigraphic and magnetostratigraphic data from Daams et al. (1999), Agustí et al. (2001), Larrasoaña et al. (2006), van der Meulen et al. (2011) and Gradstein et al. (2012) are used to construct this scheme.

The resolution of the biostratigraphic data in the lower and middle Miocene is irregular, ranging from $100 \mathrm{ka}$ to $3 \mathrm{Ma}$ depending on the biozonation scale and chosen time interval. The MN biozonation has lower resolution, namely, between 1 and $3 \mathrm{Ma}$. The local biozonation presents higher resolution, namely, between $200 \mathrm{ka}$ and $2.5 \mathrm{Ma}$ in the lower Miocene and between $100 \mathrm{ka}$ and $1.5 \mathrm{Ma}$ in the middle Miocene.

\section{Geological context}

The Ebro basin is one of the largest Cenozoic intermontane basins in the Iberian Peninsula. This basin is bounded by the Pyrenean Range, the Iberian Range and the Catalonian Coastal Range (Fig. 2), which have provided the basin with sediments since the latest Cretaceous. Its evolution is mainly related to the development of the South Pyrenean fold-and-thrust belt and represents the latest stage of development of the South Pyrenean foreland basins. The structural development of the South Pyrenean fold-and-thrust belt was complex and involved several successive thrust sheets that developed westward and southward (Cámara and Klimowitz, 1985; Capote et al., 2002, Withchurch et al., 2011) from the Late Cretaceous to the Miocene because of oblique collision between the Iberian and Eurasian plates (Choukroune, 1992). These thrusts involved both the Variscan basement, which had the structure of an antiform stack in the Axial Zone, and the Mesozoic and Cenozoic cover, which was mainly detached from the basement, to the south of the Axial Zone. From the upper Santonian, the Pyrenean structural development caused the formation of several foreland basins that were incorporated into the orogen during successive thrust emplacements (Puigdefábregas and Souquet, 1986; Teixell and García-Sansegundo, 1995; Teixell, 1998; Simo, 2004). During the late Eocene (36 Ma; Costa et al., 2010), the South Pyrenean foreland basins became fully continental. The fluvial systems first developed largely parallel to the orogen (Fig. 3A), as did the previous turbiditic systems in the Eocene foredeep basins (Barnolas et al., 2004). Later, a number of large, orogen-transverse distributary fluvial systems formed because of the structural development of 
A
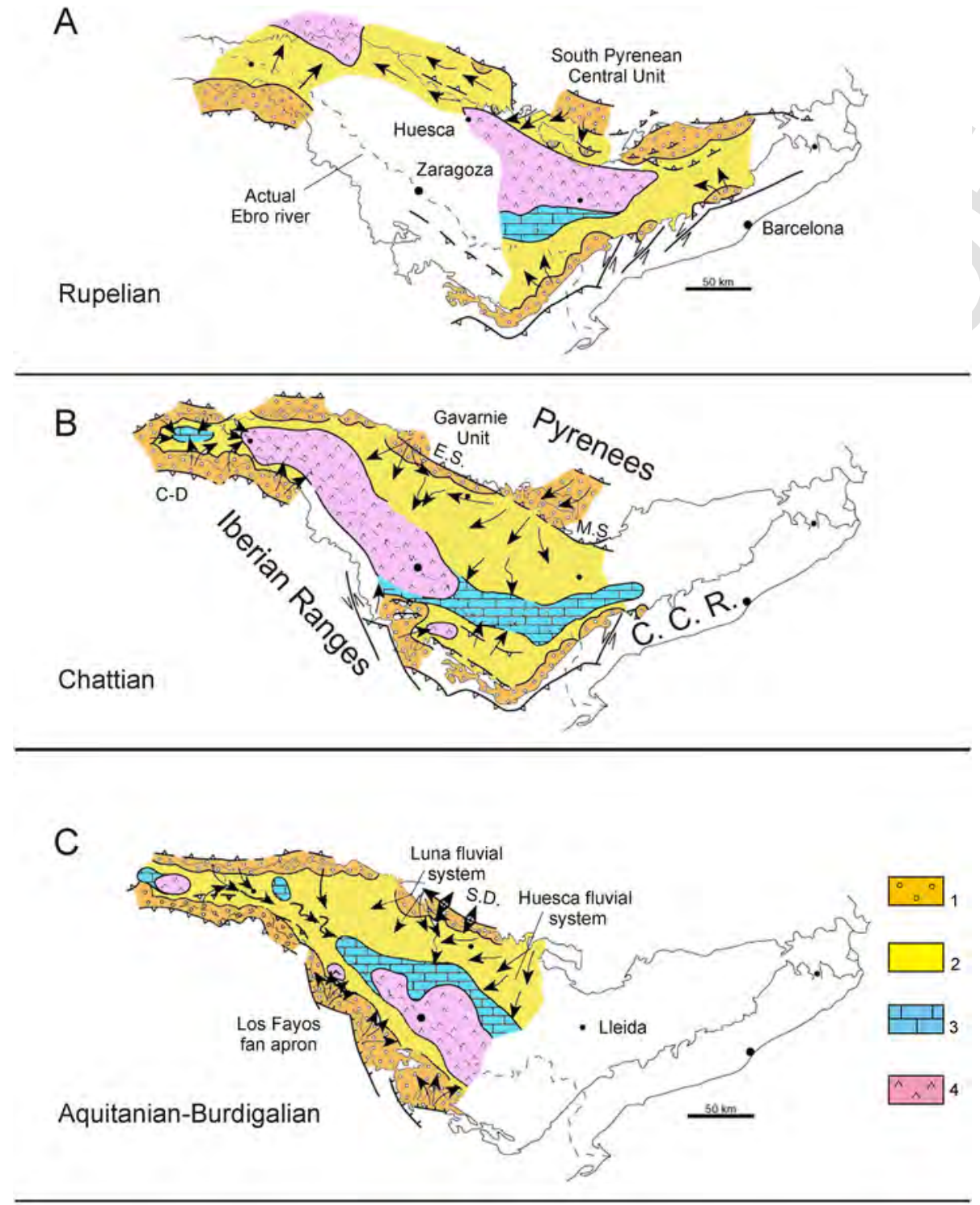

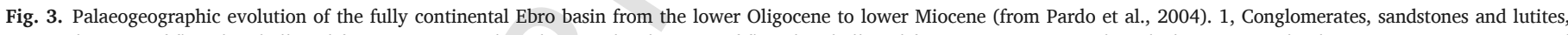

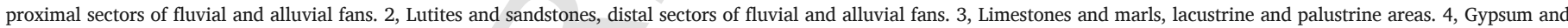
marls, evaporitic lacustrine areas. E.S., External Sierras. M.S., Marginal Sierras. C-D, Cameros-Demanda thrust. S.D., Santo Domingo anticline.

the South Pyrenean frontal thrust (type 3 from Allen et al., 2013; Fig. 3B, C). These systems fed the Ebro basin and emptied into a large lacustrine system in the basin centre. The lacustrine system migrated southward through the Miocene as the basin depocentre shifted because of the Pyrenean uplift (Pérez et al., 1994; Muñoz et al., 2002; Pardo et al., 2004). From the middle to late Miocene, the Ebro basin opened and drained to the Mediterranean Sea, beginning the erosional emptying of the basin (García-Castellanos et al., 2003; Arche et al., 2010; Urgeles et al., 2011; Vázquez-Urbez et al., 2013).

The eight TSUs that form the Ebro basin fill (Fig. 2) were first dated by using vertebrate biostratigraphy (e.g., compilations in Villena et al., 1992; Cuenca et al., 1992; Muñoz et al., 2002). This work focuses on 12 sections that crop out in the central sector of the basin and span units T4 to T7 (Fig. 2), with a total stratigraphic thickness of ca. $1000 \mathrm{~m}$. The corresponding sedimentary rocks are largely devoid of structural deformation. The deposition of units T4 to T7 was related to 1 ) two main fluvial orogen-transverse distribu- tary systems of Pyrenean provenance but with different catchment areas (Huesca and Luna systems; Hirst and Nichols, 1986) and 2) an apron of alluvial fans with limited reach, e.g., the Los Fayos alluvial fan, which developed along the Iberian margin (Villena et al., 1996b; Muñoz et al., 2002; Pardo et al., 2004) (Fig. 2). These systems fed a central lacustrine system in which the deposition of evaporites and carbonates occurred. Lake-water-level changes that resulted from climate variations (typical magnitude of $\sim 6 \mathrm{~m}$ or less) played an important role in the spatial and temporal distribution of the lacustrine facies (Arenas and Pardo, 1999).

The Huesca system fed the Sierra de Alcubierre area (sections 1, 2, 3 and 4; Fig. 2). The Luna system fed the areas of Montes de Castejón (sections 5 and 6) and Bardenas Reales (sections 8, 9 and 10). The catchment areas of the Luna and Huesca systems included the Palaeozoic to lower Oligocene rocks of the structural units from the Axial Zone to the External Sierras (Arenas et al., 2001; Yuste et al., 2004; Luzón, 2005). A number of small alluvial fans were sourced exclusively from the External Sierras (Hirst and Nichols, 
1986; Arenas et al., 2001; Luzón, 2005). One of these fans, the Agüero fan in the Luna system, supplied the San Felices area with sediment (section 7). The Bardenas Reales area may have received sediment supply from a trunk, axially directed, south-eastward-flowing fluvial system (Muñoz et al., 2002; Fig. 3C). In turn, the catchment area of the Los Fayos alluvial fan (Tarazona area) mainly contained the Mesozoic rocks of the Iberian Range. This fan was associated with the deposits in sections 11 and 12 (Fig. 2). At present, the studied areas (Sierra de Alcubierre, Montes de Castejón, Bardenas Reales and Tarazona) are physically disconnected from each other by modern fluvial valleys.

\section{Previous age calibration works in the studied region}

Stratigraphic, magnetostratigraphic and biostratigraphic results from previous works that involved the studied area in the Ebro basin were used to achieve the purpose of this study. The relevant information is summarized below.

Arenas (1993) and Arenas and Pardo (2000) measured and correlated several stratigraphic sections in the central sector of the basin (sections 2 to 6 in Fig. 2) that span TSUs T5 to T7 (lower-middle Miocene) by using the TSA methodology.

Magnetostratigraphic studies in Miocene lacustrine and distal alluvial deposits of these sections were performed in the Sierra de Alcubierre (Pérez-Rivarés et al., 2002) and the Montes de Castejón (Pérez-Rivarés et al., 2004).

In the Sierra de Alcubierre area, 726 magnetostratigraphic sites were sampled through a 636-m-thick succession (Albalatillo, Lanaja and San Caprasio sections; 2, 3 and 4 in this work, Fig. 2). The resulting composite magnetostratigraphic succession (28 magnetozones) spans from chron $6 \mathrm{Ar}$ to chron $5 \mathrm{ABn}$, which represents approximately $8 \mathrm{Ma}$ in the early and middle Miocene. The average duration of the chrons in this time interval is $275 \mathrm{ka}$. This previous study presented a very extensive, continuous and characteristic magnetostratigraphic record, which is the main value of its credibility: at the time of publication (Pérez-Rivarés et al., 2002), no valid biostratigraphic data were known in the area. An important point for the age calibration of this succession was the age of a volcanic ash level in section 2, which was dated by ${ }^{39} \mathrm{Ar} /{ }^{40} \mathrm{Ar}$ at $19.7 \pm 0.3 \mathrm{Ma}$ (Odin et al., 1997; Van Dam et al., 2006). Later, Agustí et al. (2011) provided relative ages from six new micromammal fossil sites in the Sierra de Alcubierre, which ranged from biozone MN3 to biozone MN5. The ages of these fossil sites were consistent with the magnetostratigraphic data of Pérez-Rivarés et al. (2002). This magnetostratigraphic work provided dates for the T5/T6 and T6/T7 boundaries. Moreover, these magnetostratigraphic data are crucial to further correlation because they provide a time anchor between section 1 in this work and the magnetic reference scale (i.e., Gradstein et al., 2012). This information is important for dating the T4/T5 boundary in the Sierra de Alcubierre.

In the Montes de Castejón (Pérez-Rivarés et al., 2004), the magnetostratigraphic study was based on the analysis of 196 magnetostratigraphic sites that were sampled through a 240 -m-thick succession (sections 5 and 6 in this work; Fig. 2). Local magnetostratigraphy yielded a sequence of 12 magnetozones that could be correlated with the GPTS interval from C5Cr to C5ADn (between 17.2 and 14.1 Ma.). The Montes de Castejón composite magnetostratigraphic succession did not have biostratigraphic or radiometric support and showed a continuous and characteristic magnetostratigraphic record, which permitted reliable correlation with the GPTS and was consistent with previous stratigraphic correlation in the area (Arenas, 1993; Arenas and Pardo, 2000). The composite succession provided a magnetostratigraphic date for the T5/T6 boundary.
Farther west in the Ebro basin, Larrasoaña et al. (2006) performed a biomagnetostratigraphic study in the Bardenas Reales area (sections 8, 9 and 10 in Fig. 2) and proposed a correlation between the lower-middle Miocene deposits (Tudela Formation) and units T4 to T6. This study was based on 331 magnetostratigraphic sites through a 790-m-thick composite section. The resulting magnetic polarity sequence included 16 magnetozones, provided an independent correlation to the GPTS and enabled the accurate dating of previously known and new Ramblian (upper portion of the lower Miocene) fossil sites in the Tudela Formation. The chrons in this time interval (C6An to $\mathrm{C} 5 \mathrm{Br}$ ) have an average duration of $275 \mathrm{ka}$. Although this work was an important contribution to the magnetostratigraphy of the Ebro basin, with remarkable biostratigraphic support, its relevance for the present work is limited because the Bardenas Reales area lacks a specific TSA, and the exact position of the TSU boundaries is thus not yet known.

Oliva-Urcia et al. (2016) presented new magnetostratigraphic results from the syntectonic fluvial sediments of the Campodarbe Formation (upper Eocene-Oligocene) in the northern-central sector of the basin (San Felices area, section 7, Fig. 2). These results were combined with previously acquired data (Hogan and Burbank, 1996) and the stratigraphic correlation of Arenas et al. (2001) in a composite section that consisted of 46 magnetozones. The upper portion of this composite section (section 7 in Fig. 2) included the T4/T5 boundary. This time interval has an average chron duration of $225 \mathrm{ka}$.

In the western area (Tarazona area; sections 11 and 12, Fig. 2), mammal biochronological information that was provided by Murelaga et al. (2008) included a revision of previously known mammal fossil sites that were reported from the Middle Miocene in this area in addition to two new fossil sites in the upper portion of section 11. The biostratigraphic attributions of this fossil site compilation (7 sites through $2.5 \mathrm{Ma}$ ) were used in this work as anchoring points for the construction of the magnetostratigraphic correlation.

\section{Magnetostratigraphic results}

Together, the previous magnetostratigraphic studies in the preceding section provide a solid age framework for the TSU boundaries. However, a) the age of the T4/T5 boundary is not yet well constrained and b) the T6/T7 boundary has only been dated in section 4 (Pérez-Rivarés et al., 2002). Thus, we focus on providing new magnetostratigraphic data for two areas: 1) the Ontiñena section of the Sierra de Alcubierre (section 1, Figs. 2 and 4), which spans unit T4 (as mapped by Luzón, 2001) and lies within the distal portion of the Huesca fluvial system, and 2) the Lugar-Melero and Umbría Alta sections of the Tarazona area (sections 11 and 12, Figs. 2 and 4), which span units T6 and T7 (as interpreted by Vázquez-Urbez et al., 2013) and lies within the proximal and distal portions of the Los Fayos alluvial fan.

\subsection{Palaeomagnetic analyses}

The mean of the initial NRM intensities of the studied rocks from section 1 is $18 \times 10^{-5} \mathrm{Am}^{-1}$, and the intensities range from $68 \times 10^{-6} \mathrm{Am}^{-1}$ to $83 \times 10^{-4} \mathrm{Am}^{-1}$. For sections 11 and 12 , the initial NRM values range from $10 \times 10^{-6} \mathrm{Am}^{-1}$ to $14 \times 10^{-2} \mathrm{Am}^{-1}$, and the mean value is approximately $18.3 \times 10^{-3} \mathrm{Am}^{-1}$. The highest NRM intensities correspond to some reddish and orange mudstones that occur in the lower portion of section 12. The mean NRM values are higher in Sections 11 and 12 than in Section 1 and are likely related to the Fe content. The predominance of samples that consist of reddish and orange mudstones in sections 11 and 12 com- 


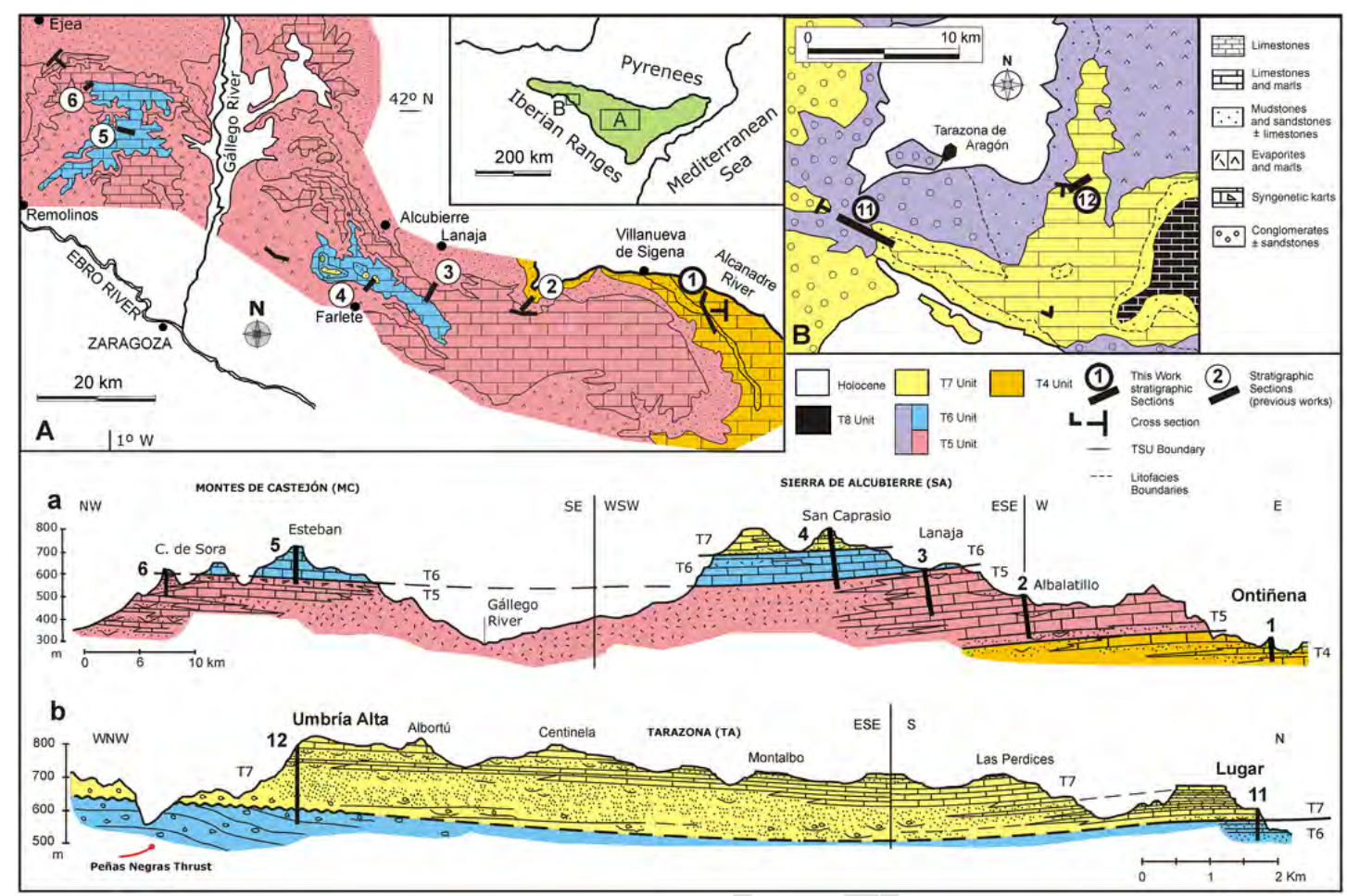

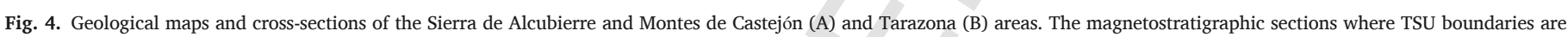
recognised are indicated (T4/T5, T5/T6 and T6/T7).

pared to section 1 may bias the differences in the NRM, but the higher NRM values are a response to an abundance of iron mineralizations in the Palaeozoic and Triassic rocks in the catchment area of sections 11 and 12 (IGME, 1975).

After the palaeomagnetic analysis, a viscous magnetization was removed after heating to $100^{\circ} \mathrm{C}$ in all the specimens $\left(150\right.$ or $200^{\circ} \mathrm{C}$ in some samples from section 12). A secondary north-oriented that was component that was related to the present-day geomagnetic field was isolated at approximately 350 to $400^{\circ} \mathrm{C}$ (occasionally $450^{\circ} \mathrm{C}$ ). Above this temperature, a characteristic remanent magnetization (ChRM) with either normal or reversed polarity can be identified (Fig. 5). In most of the limestone samples from section 1 , the ChRM showed maximum unblocking temperatures that were close to $430^{\circ} \mathrm{C}$. In sections 11 and 12 , the limestone samples displayed maximum unblocking temperatures from 550 to $580^{\circ} \mathrm{C}$. In most of the mudstone samples, the maximum unblocking temperatures ranged from 580 to $680^{\circ} \mathrm{C}$ with the exception of grey and brown mudstones from section 1 , which were totally demagnetized at $530^{\circ} \mathrm{C}$. The maximum unblocking temperatures suggest that magnetite and haematite were the main carriers of magnetization in the mudstone samples and that magnetite was the dominant carrier in the limestone samples (Fig. 5). A class B positive reversal test was obtained for the samples from the Tarazona area (critical angle: $8.0^{\circ}$, angle between normal and reverse polarity sets: $7.0^{\circ}$, probability of exceeding this angle: 0.104), indicating the successful isolation of the ChRM component (Fig. 6). However, the result of the test for section 1 was negative (critical angle: $11.0^{\circ}$, angle between normal and reverse polarity sets: $14.5^{\circ}$, probability of exceeding this angle: 0.104 ), which brought the isolation of a ChRM into question for this section. However, the normal and reversed polarity sets yielded antipodal Fisherian means, and the resulting mean direction revealed no significant vertical axis rotations, which is consistent with the expected palaeomagnetic declination for the Miocene in the north-eastern Iberian Peninsula
(Smith, 1996). ChRM directions were used to obtain the latitude of the virtual geomagnetic pole (VGP) at each site (Fig. 7).

A local magnetic stratigraphy was produced for every studied section, i.e., 1, 11 and 12 (Fig. 7). After the exclusion of unreliable, short-term magnetic reversals, five magnetozones were identified in section 1 , eleven magnetozones were identified in section 11, and eleven magnetozones were identified in section 12 (Fig. 7).

\subsection{Correlation with the Geomagnetic Polarity Time Scale (GPTS)}

In the Sierra de Alcubierre, photogeological correlation allowed the positioning of the top of section 1 approximately $20-30 \mathrm{~m}$ below the base of section 2 (Fig. 8). The base of section 2 had previously been set within chron C6Ar (Pérez-Rivarés et al., 2002). Despite the lack of an overlapping record, the close stratigraphic position of these two sections and the similarity between the local magnetostratigraphic pattern of section 1 and the GPTS pattern (from Gradstein et al., 2012) allowed the correlation of the base and top of section 1 with chrons C6C.2r and C6AAr.1r, respectively (Fig. 8). Magnetozone N2 was correlated with chron $\mathrm{C} 6 \mathrm{Cn} .1 \mathrm{n}$ and magnetozone N3 was correlated with the full chron C6Bn. Chron C6Bn.1r was not identifiable within section 1. This correlation indicated that section $1(141 \mathrm{~m})$ represents $1.6 \mathrm{Ma}$ of geologic time between 23 and $21.4 \mathrm{Ma}$.

In the Tarazona area, a reliable physical correlation between sections 11 and 12 could be traced for several kilometres within the study area (Fig. 4). The resulting composite magnetostratigraphy of the Tarazona area yielded a total of $240 \mathrm{~m}$ and consisted of 15 magnetozones, 7 normal (N7-N13) and 8 reversed (R7-R14). A correlation with the GPTS (Fig. 9) was presented based on the characteristic reversal pattern of the composite magnetostratigraphy of the Tarazona area and the mammal biochronological information that was provided by Murelaga et al. (2008). Of particular relevance was the Tarazona de Aragón (TA) fossil site (Astibia, 1986, 

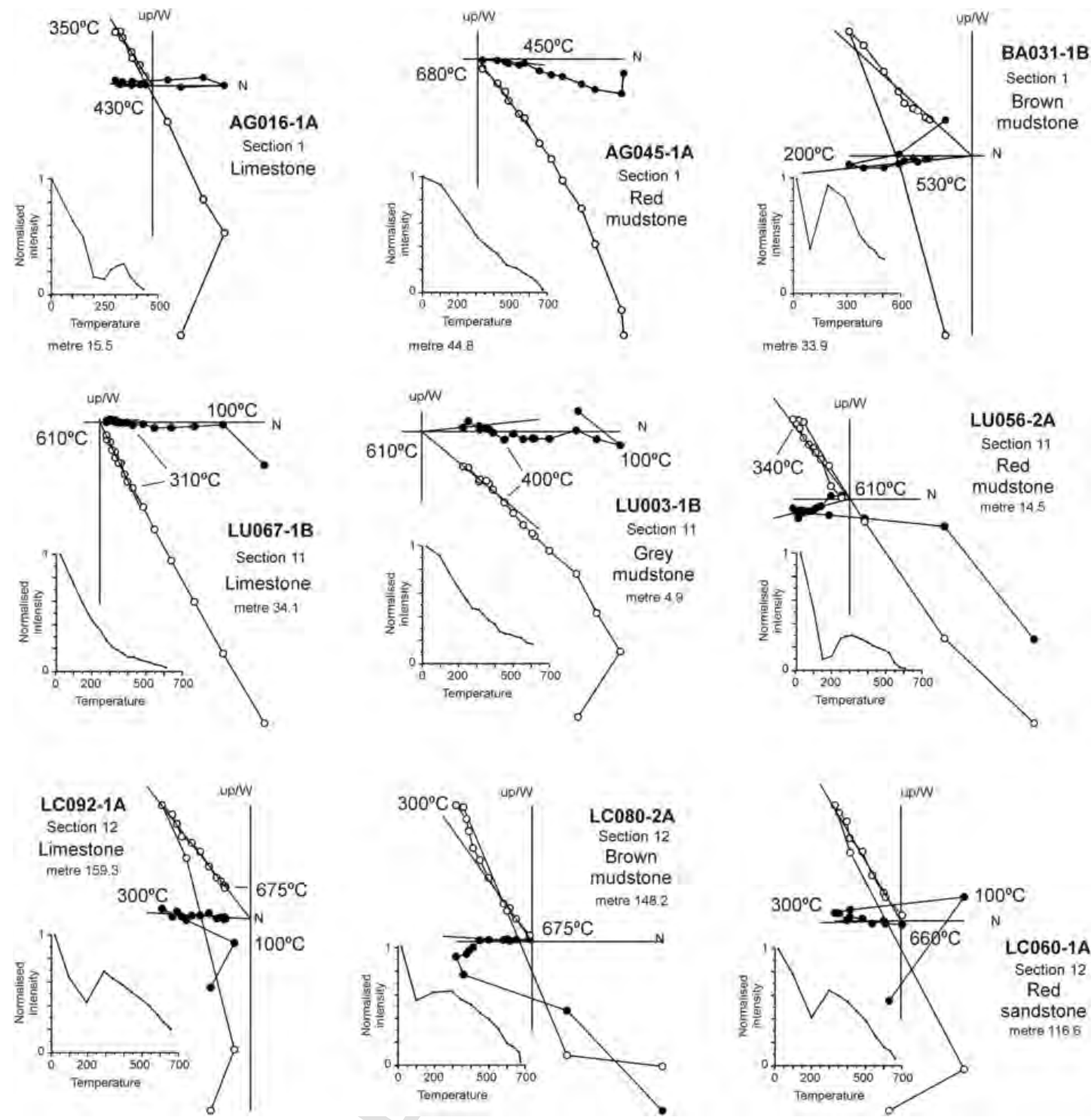

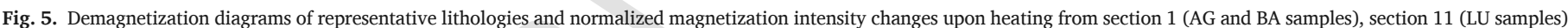

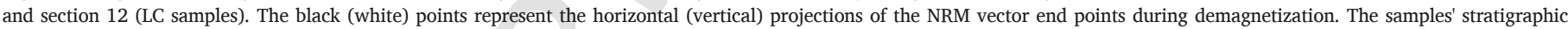
positions in metres are shown in Fig. 7.

1987; Valdés et al., 1986), the richest fossil site in terms of taxa from the Aragonian continental stage in the Ebro basin. This site was attributed by Astibia $(1986,1987)$ and Valdés et al. (1986) to the local biozone D (according to the zonation by Daams and Freudenthal, 1981) or MN5 (according to the biozones by Mein, 1975). Furthermore, the localities Melero 20 and Melero 30 (ME 20 and ME 30, Fig. 9) were attributed to zones E (or MN5) and F (or MN6), respectively (Murelaga et al., 2008). Together, these data permitted a feasible correlation by anchoring the normal magnetozones N7 to N9 with chrons C5ADn to C5AB (Fig. 9). The La Ciesma fossil site (LC) contains both macromammalian and micromammalian fossil faunas (Azanza, 1986). The former were assigned to MN7/8 (Azanza, 1986; Domingo et al., 2007), and the latter were considered to be mainly Vallesian faunas (Azanza et al., 1988; Cuenca et al., 1992). These observations are consistent with the correlation of the reversed magnetozones R11, R12 and R13 with the reversed chrons C5Ar and C5An (Fig. 9). Moreover, two geographically close fossil sites (BO and EBU, Fig. 9) were correlated to the studied sections through stratigraphic correlation (i.e., physical continuity of strata; Pérez Rivarés, 2016). The ages of these two fossil sites confirmed the preceding consideration. In this correlation, chrons C5Ar.2n to C5Ar.1n were not convincingly identified. Both chrons could possibly be represented by magnetozone N11 (Fig. 9).

The lower portion of section 12 showed a change in magnetic polarity at approximately $36 \mathrm{~m}$ from the base (Fig. 7) within a conglomeratic interval that coincided with an unconformity. This unconformity corresponds to the T6/T7 boundary in section 12 (Pérez Rivarés, 2016; Fig. 4). This lacuna precludes magnetostratigraphic correlation with the GPTS, so the lower portion of section 12 (magnetozone R7) and the T6/ T7 boundary in section 12 could not be dated.

Although the magnetic quality of the youngest samples in section 12 was poor (Fig. 7), the estimated magnetic polarity indicated that the upper portion of section 12 could represent chron C5r.3n (ca. 11.6 Ma). This age assignment implies a deposition rate of $6.64 \mathrm{~cm} / \mathrm{Ka}$ for this ca. 35-m-thick lacustrine interval, which is consistent with the rates from this and other Miocene lacustrine sections in the Ebro basin (Pérez-Rivarés et al., 2002, 2004). 

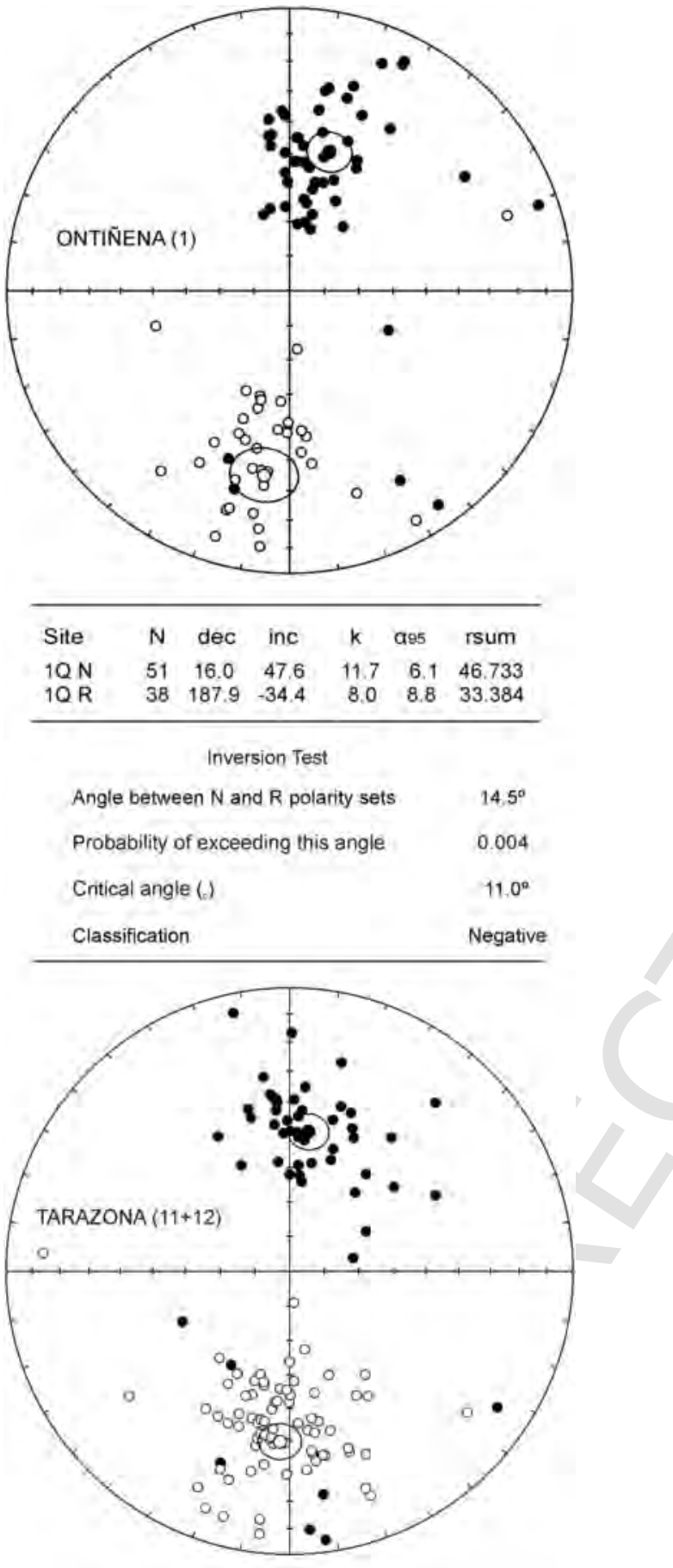

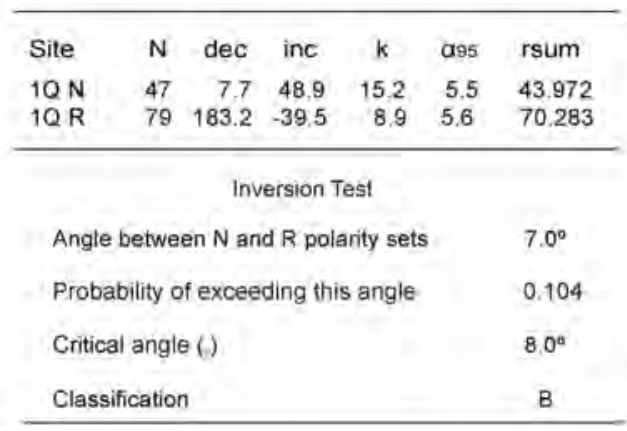

Fig. 6. Equal-area stereographic projections of the characteristic directions (normal and reversed polarities). The mean directions with $95 \%$ confidence limits are displayed. $\mathrm{N}$, number of directions; dec, declination; inc, inclination; $k$, precision parameter; $\alpha_{95}$, confidence limit.

These results indicate that the studied sections at Tarazona (excluding magnetozone R7) span C5ADn to C5r.3r, with an age of ca. $14.6 \mathrm{Ma}$ for the base and ca. $12 \mathrm{Ma}$ (11.6 Ma if the above argument is considered valid) for the youngest sediments in the analysed succession.

\subsection{Magnetostratigraphic dating of TSU boundaries in the Ebro basin}

The correlations of the new magnetostratigraphic sections (sections 1,11 and 12) enable us to date the TSU boundaries at two new sites (Fig. 10). In the Sierra de Alcubierre, the position of the T4/T5 boundary has been recognised at the top of section 1 according to the mapping of Luzón (2001), where this boundary was identified and correlated between several sections in the eastern-central sector of the Ebro basin. This boundary should be between chron C6AA.1r and the lower portion of chron C6Ar. This result produced an age estimation of $21.3 \mathrm{Ma}$ (within chron C6AA.1r) for the T4/T5 boundary.

In the Tarazona area (section 11), the sedimentary break that was reported by Pérez (1989), which was later identified by Vázquez-Urbez (2008) and Vázquez-Urbez et al. (2013) as the T6/T7 boundary, is located between chrons C5ACr and C5ADn. This location permitted an accurate estimation for the age of the T6/T7 boundary, specifically, 14.16 Ma.

These new results, alongside the results from the previous works that were cited in chapter 4, enabled us to estimate the approximate thickness and duration of three TSUs in the Ebro basin (Fig. 10): 1) unit T5 ca. $450 \mathrm{~m}$ and $5.4 \mathrm{Ma}$; 2) unit T6 - ca. $120 \mathrm{~m}$ and $2.2 \mathrm{Ma}$; and 3) unit T7 - minimum of $225 \mathrm{~m}$ and $2.8 \mathrm{Ma}$.

\section{Discussion}

6.1. Conformable vs hiatal nature of the genetic stratigraphic unit boundaries.

In the area covered by this work, the boundaries between the TSUs along the margins of the Ebro basin were characterised at each sector as angular or syntectonic unconformities that formed in relation to certain tectonic structures at the bounding ranges (Muñoz et al., 2002; Pardo et al., 2004). Far from the basin margins, ca. $50 \mathrm{~km}$ from the Iberian Range, the only unconformable relation was associated with the lower boundary of unit T4. This unit was deposited in relation to the activity of a socle thrust sheet (i.e., the Puigmoreno thrust sheet, Pardo et al., 2004) in the eastern extreme of the Cameros thrust (Guimerà, 2004). The remaining TSUs in the basin centre are supposed to be conformable with each other because no paraconformities were detected across the sections. Indeed, the conformable character of the studied TSU boundaries in the basin centre is supported by the good agreement between the local composite magnetostratigraphic section and the GTPS, with all chrons being present in the study area. Moreover, chrons as short as C5Dr.1n (23 ka) were detected in the local magnetostratigraphic section 3 (Fig. 8). 
11 LUGAR-MELERO

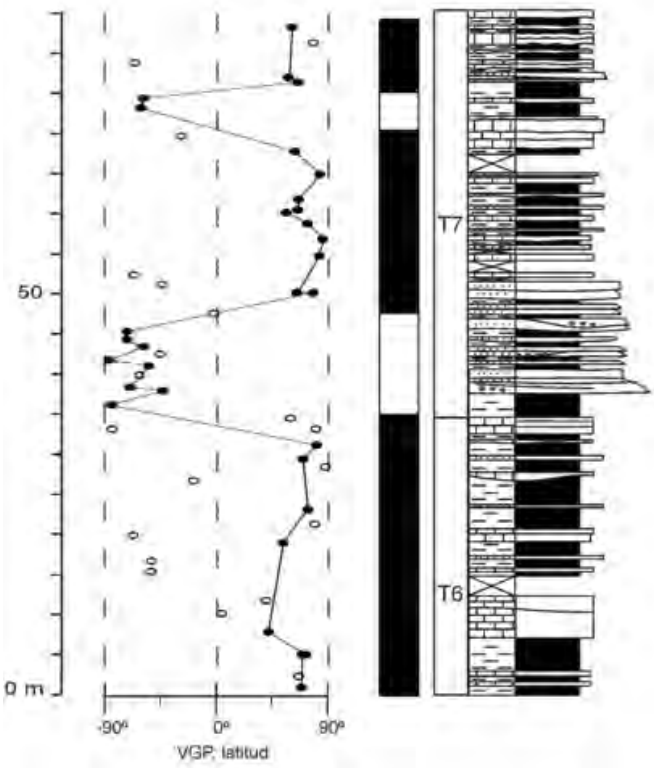

1 ONTINEENA

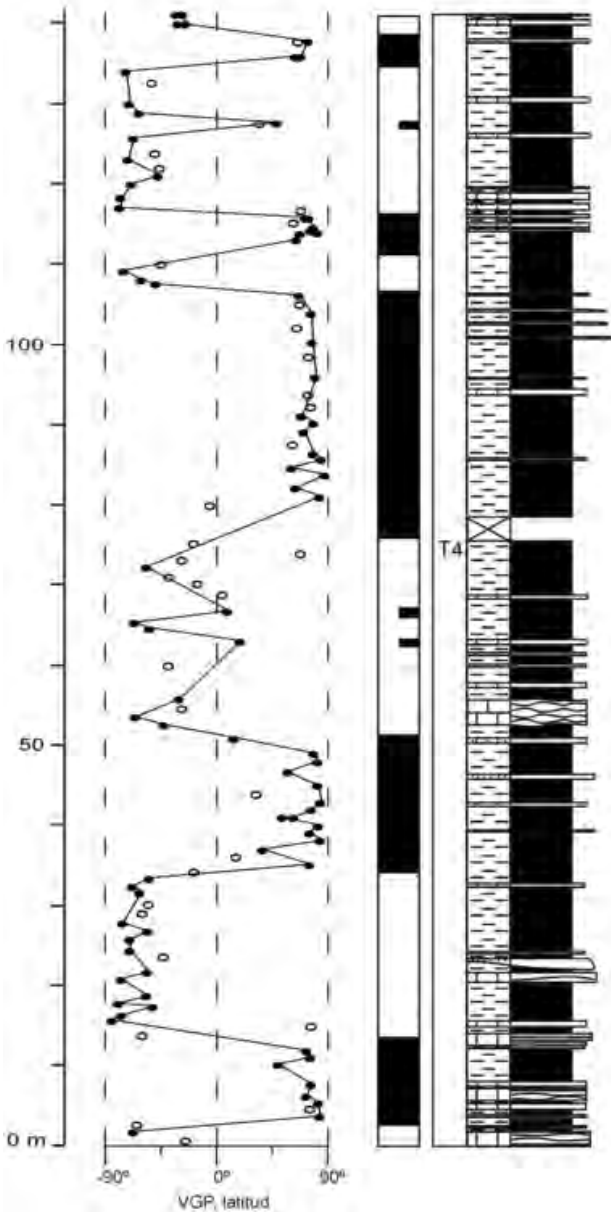

12 UMBRIA ALTA

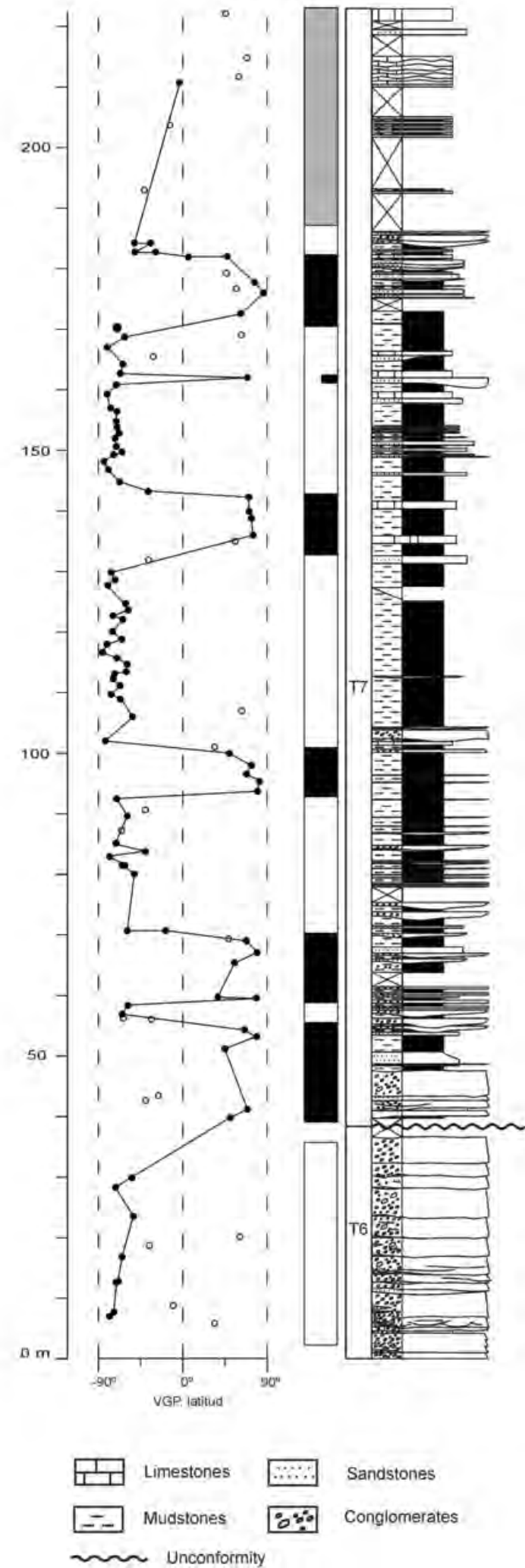

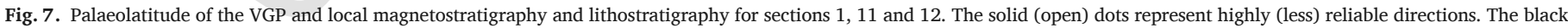

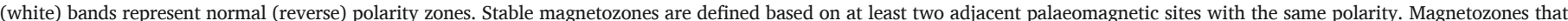
are represented by half-length bars denote one-site reversals. TSUs in these sections are indicated: T4, T6 and T7. 


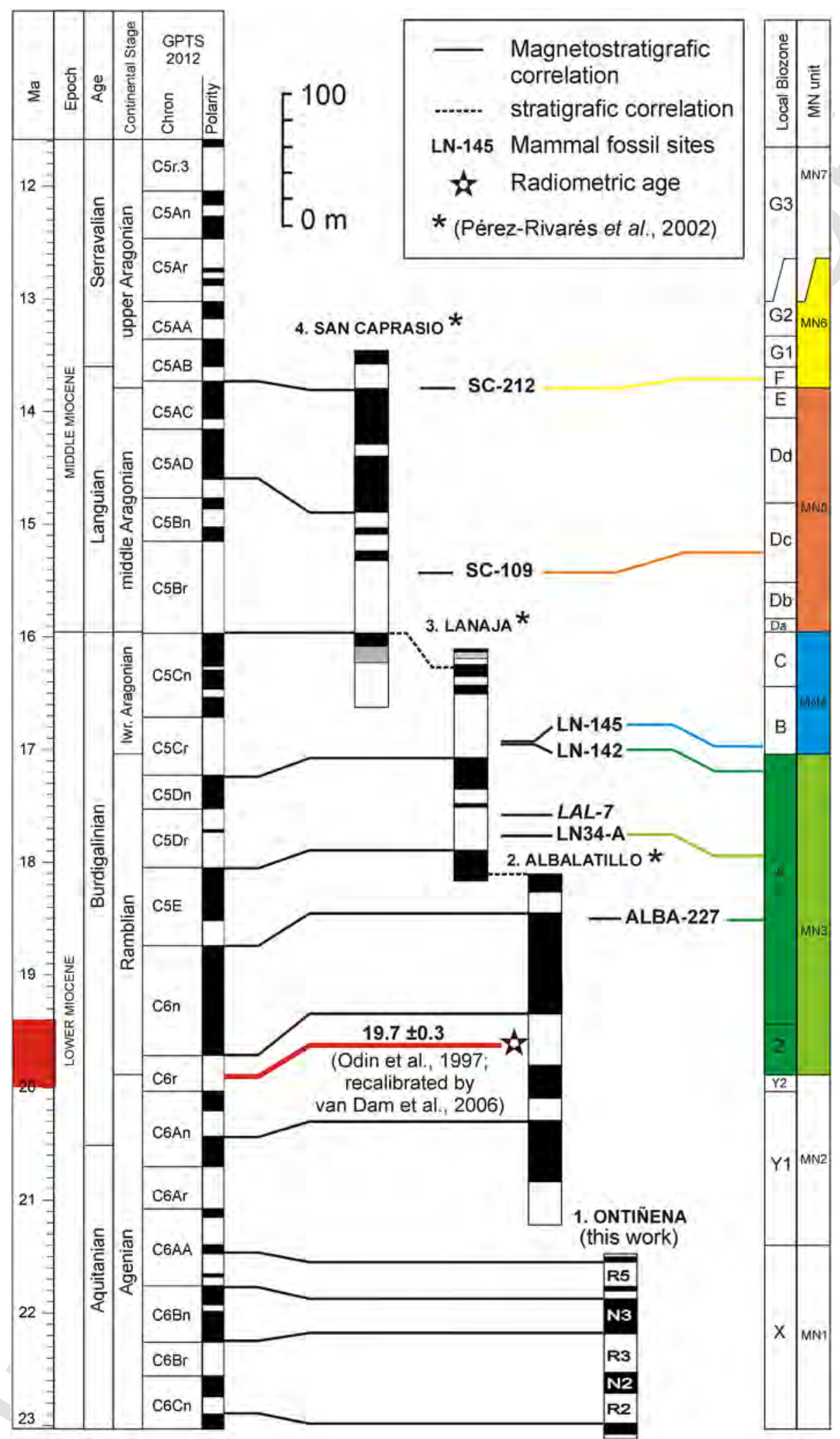

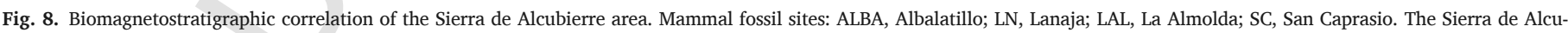
bierre mammal sites were described by Agustí et al. (2011). The mammal sites in italics were not found in these sections but were approximately located. 


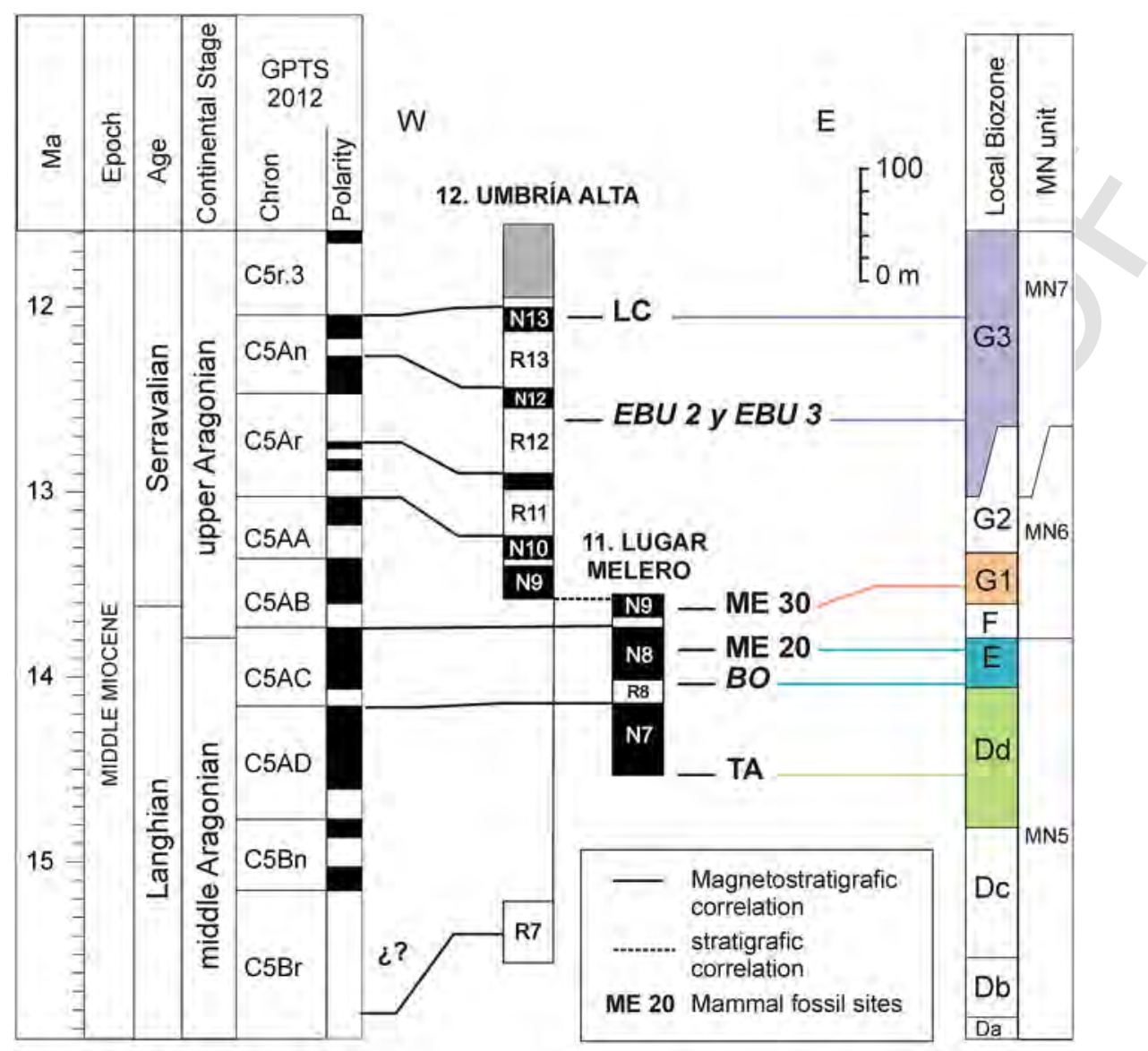

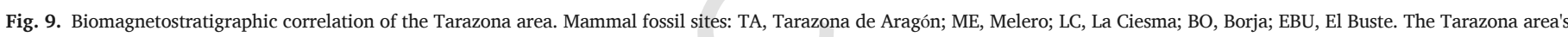
mammal sites were compiled by Murelaga et al. (2008). The mammal fossil sites in italics were not found in the sections but were approximately located.

\subsection{Evaluation of the degree of diachroneity of the TSU boundaries through the Ebro basin}

The boundaries between genetic stratigraphic units are generally considered synchronous geologic timelines where they are conformities (Garrido-Megías, 1973; Mitchum et al., 1977; Megías, 1982; Vail, 1987; González et al., 1988; Pardo et al., 1989). Thus, two points of a stratigraphic surface are qualified as synchronous if the degree of diachroneity is below the resolution of the applicable dating methods. However, other authors use the terms "low and high diachrony" (cf. Catuneanu, 2006; Embry, 2009), so the concept "synchronous" would be equivalent to "low diachrony". The ages of the boundaries between TSUs T4, T5, T6 and T7 within the Ebro basin were compared in this study to test this concept (Fig. 11). Thus, the age of each boundary was estimated by magnetostratigraphic methods at the different areas that were considered in this work (see Methods, chapter 2).

\subsubsection{T4/T5 boundary}

Oliva-Urcia et al. (2016) proposed a new magnetostratigraphy for unit T3 (Campodarbe Formation) in the Pyrenean margin and confirmed previous age estimates for units T4 and T5 in the Luna system (Uncastillo Formation; section 7, Figs. 2 and 11), which had been mapped by Arenas (1993). This proposal was based on new magnetostratigraphic data from the Campodarbe Formation, previously existing magnetostratigraphic data from both formations (from Hogan and Burbank, 1996) and a reinterpretation of previ- ous data from the Uncastillo Formation, such as those by Arenas et al. (2001). Together, these data allowed Oliva-Urcia et al. (2016) to suggest that the T4/T5 boundary should be located within chron C6AAr.2r, at approximately $21.5 \mathrm{Ma}$.

Pérez-Rivarés et al. (2002) proposed that the T4/T5 boundary in section 2, within the distal sector of the Huesca fluvial system in the Sierra de Alcubierre (Fig. 2), could be located within chron C6An.2n. However, the authors warned that the poor quality of the exposures did not allow unambiguous correlation and noted that the proposed position for the T4/T5 boundary was the youngest within the possible rank. In fact, Arenas (1993) suggested that this boundary should be a few metres below the base of section 2 . Section 1 in this study supports the conclusion that the most plausible position for the T4/T5 boundary lies between the top of section 1 and the base of section 2 (Fig. 10). Accordingly, this boundary should be between chron C6AA.1r and the lower portion of chron C6Ar. This result produced an age estimation of 21.3 Ma (within chron C6AA.1r) for the T4/T5 boundary.

Larrasoaña et al. (2006) conducted a magnetostratigraphic study in the Lerín and Tudela Formations in the Bardenas Reales area (Fig. 2, sections 8, 9 and 10). According to the overall stratigraphy of this portion of the basin (Muñoz et al., 2002; Pardo et al., 2004), the lithological change from the evaporitic deposits of the Lerín Formation to the carbonate and fine detrital deposits of the Tudela Formation may correspond to or be close to the T4/T5 boundary. In section 9 (Fig. 2), this facies change occurs within chron C6An.1n (from the magnetostratigraphy as presented by Larrasoaña et al., 2006), between 20.21 and 20.04Ma. An age of 


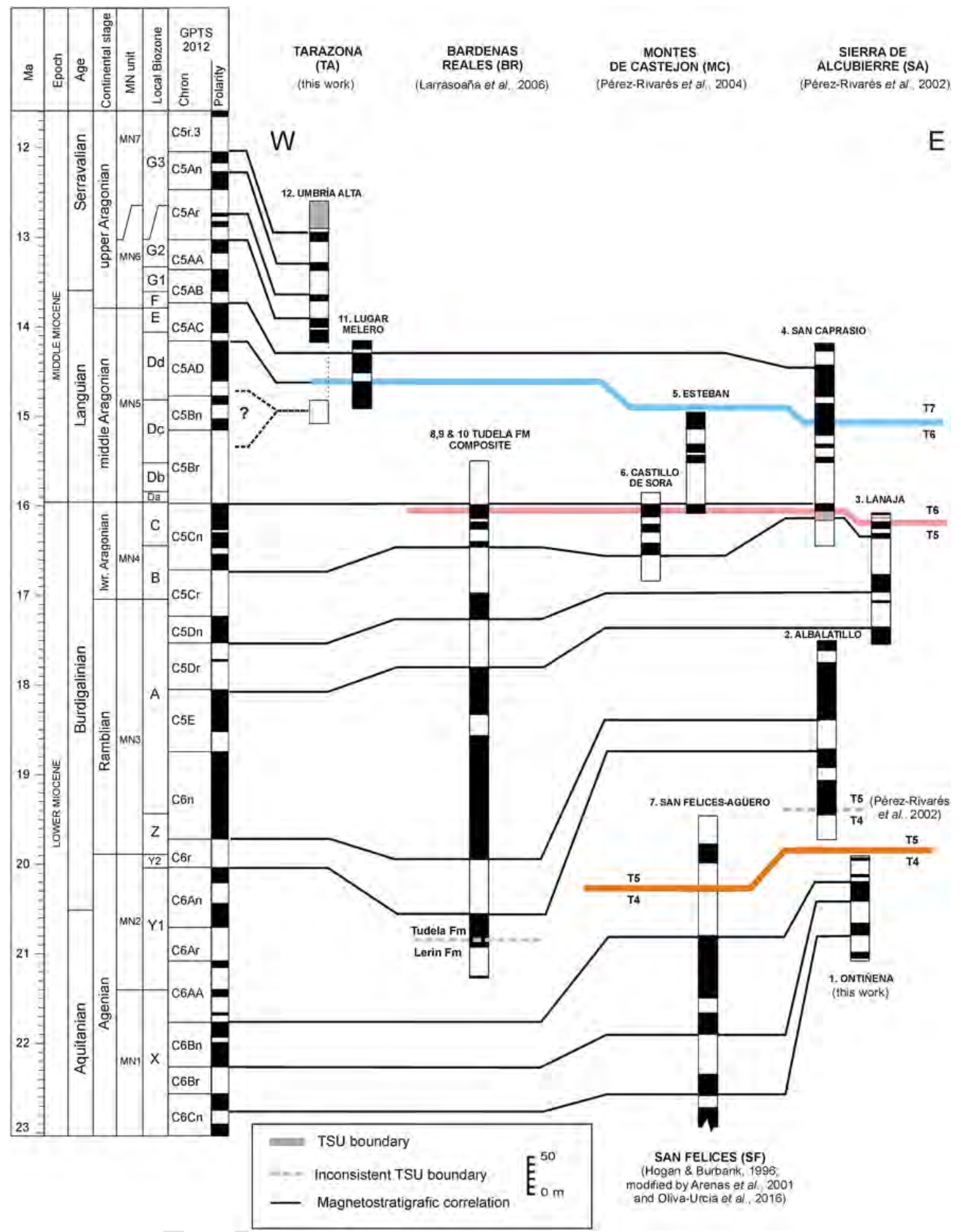

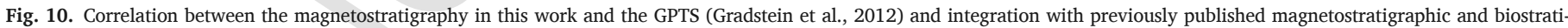

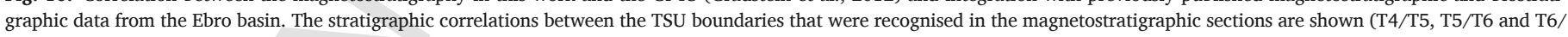
T7).

20.18Ma can then be estimated for that lithological boundary. However, this area lacks a specific TSA, and the exact position of TSU boundaries is thus not yet known. The correspondence between this lithological boundary and the T4/T5 boundary in this area has not yet been demonstrated (e.g., through mapping and stratigraphic correlation with nearby areas).

Therefore, the T4/T5 boundary has been placed between sections 1 and 2 at $21.3 \mathrm{Ma}$ (this work) and in section 7 at $21.5 \mathrm{Ma}$ (Oliva-Urcia et al., 2016). Sections 1 and 7 allow the estimation of a difference of approximately $0.2 \mathrm{Ma}$ for the T4/T5 boundary between the centre and northern margin of the basin (Fig. 11).

\subsubsection{T5/T6 boundary}

The T5/T6 boundary has been recognised in six sections in the basin centre and western-central sector (Figs. 10 and 11), including sections 3 and 4 (Sierra de Alcubierre, Pérez-Rivarés et al., 2002), sections 5 and 6 (Montes de Castejón, Pérez-Rivarés et al., 2004) and sections 8 and 9 (Bardenas Reales, as interpreted from data in 


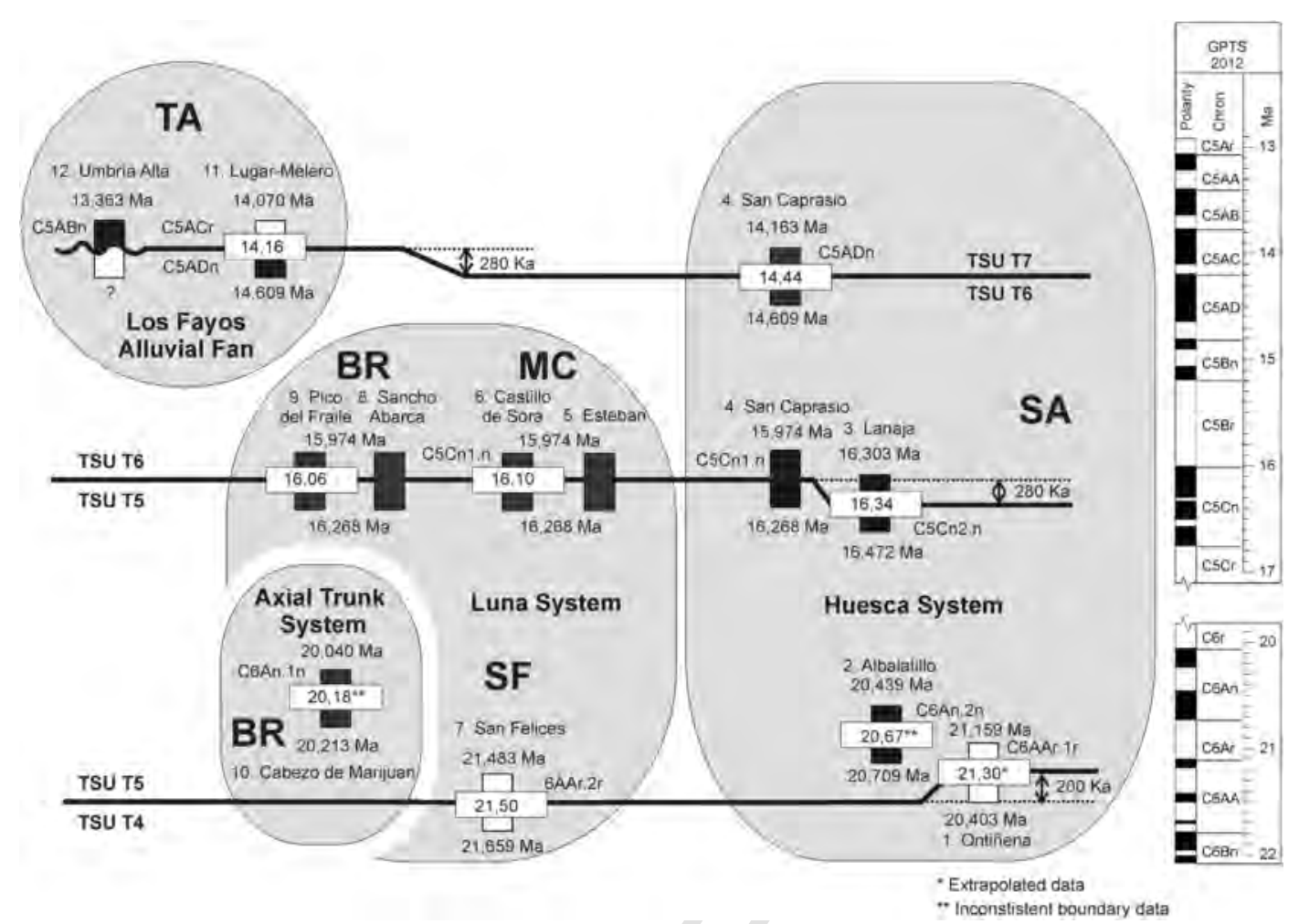

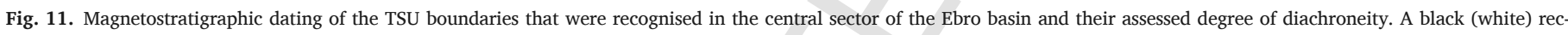

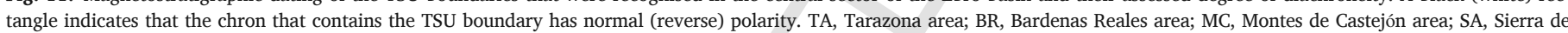
Alcubierre area; SF, San Felices area.

Larrasoaña et al., 2006). In the Bardenas Reales area, the change from reddish mudstones and ochre sandstones to grey limestones and marls represents an expansion of the carbonate lacustrine environment. This change has also been recognised in other nearby areas, including the Montes de Castejón, where the corresponding surface has been assigned to the T5/T6 boundary (Arenas, 1993; Arenas and Pardo, 2000).

Except for section 3, this boundary occurs within C5Cn.1n. This boundary has been set at approximately $16.1 \mathrm{Ma}$ in section 6 and $16.06 \mathrm{Ma}$ in section 9. Sections 4,5 and 8 do not record the base of chron $\mathrm{C} 5 \mathrm{Cn} .1 \mathrm{n}$, so the estimated age for the T5/T6 boundary at these sites is less precise. In section 3, the T5/T6 boundary (Arenas, 1993; Arenas and Pardo, 2000) occurs within chron C5Cn.2n (at approximately 16.35Ma; Fig. 11).

In summary, the age of the T5/T6 boundary varies by less than 0.3 Ma throughout the Ebro basin centre, i.e., from section 3 to sections 6 and 9 (Fig. 11). Notably, the difference in the age of this boundary between sections 6 and 9 can be no greater than ca. $40 \mathrm{ka}$. The T5/T6 boundary is not revealed as a sharp surface in section 3 , unlike in the other sections; instead, this boundary occurs within a set of marl and limestone strata. This lithological homogeneity may have caused the T4/T5 surface not to be accurately positioned, explaining the larger age difference (280 ka).

\subsection{3. $T 6 / T 7$ boundary}

The T6/T7 boundary is located within chron C5ADn in section 4 (14.44 Ma), which is linked to the Huesca fluvial system, and between chrons C5ACr and C5ADn in section 11 (14.16 Ma) in relation to the Los Fayos alluvial fan (Fig. 11). The difference in the age of this boundary is smaller than $0.3 \mathrm{Ma}$ between these two sections, that is, between the basin centre, which is linked to the evolution of the Pyrenean Range, and the southern area, which is linked to the evolution of the Iberian Range.

\subsection{Causes of diachrony in the TSU boundaries}

Magnetostratigraphic analysis indicated that the diachrony of the boundaries between TSUs (i.e., the age of the rocks at the bounding surfaces) in the Miocene Ebro basin is smaller than 0.3Ma in the basin centre, where these boundaries are most likely conformable. Although the estimated diachrony of the TSU boundaries was small, two factors could have affected our age dating: 1) methodological inaccuracies and 2) the diverse catchment areas and allogenic factors that were associated with the bounding mountain ranges.

\subsubsection{Methodological inaccuracies}

Imprecisions that are derived from the inaccurate positioning of the boundaries between units through the correlation process are of particular concern for deposits in the distal portions of fluvial and alluvial systems and in lacustrine systems. This circumstance occurs because of the difficulty in identifying the boundaries (e.g., type- 1 and -3 sedimentary breaks; Fig. 1) where they occur within intervals of homogeneous lithologies that do not show clear vertical sedimentary trends. The T5/ T6 boundary in section 3 may reflect this situation (Fig. 11) because the age of this boundary is approximately $0.3 \mathrm{Ma}$ older in section 3 than in section 4 . Therefore, the different age for the T5/T6 boundary in section 3 may be related to the uncertain or inaccurate location of this boundary within a homogeneous sequence that consists of marl and limestone strata.

\subsubsection{Provenance of fluvial and alluvial systems}

The fluvial deposits in the Ebro basin originated from different sedimentary systems that stemmed from one or more different mountain ranges. In this context, these systems may have catchment areas that lie within different structural units with distinct ex- 
tent and relief (Fig. 2). Differences in the timing and strength of tectonic deformation and climatic conditions in the ranges that bound the basin probably affected the sedimentation and provenance of the sampled successions.

Commonly, the response of alluvial systems to climatic changes is rapid (Densmore et al., 2007). Allen and Densmore (2000) considered that a minimum of $50 \mathrm{ka}$ is necessary to detect changes in catchment-fan features because of tectonic activity. Thus, these authors concluded that "observed short-term variability in the thickness and run-out distances of fan deposits are much more likely to be due to climatic changes" because catchment-fan systems rapidly adjust to changes in precipitation, which can widely affect the system. All this information referred to small fans in rift basins, similar to Death Valley.

However, the estimated diachrony for the T4/T5 boundary (which is approximately $0.2 \mathrm{Ma}$ younger in section 1 , in the Huesca system, than in section 7, in the Luna system; Fig. 11), seems too long to have been caused by climatic changes in the drainage areas. Thus, the diachrony of these boundaries was likely caused by factors other than the climate.

Magnetostratigraphic dating of the T4/T5 boundary in section 7 (Oliva-Urcia et al., 2016) was performed in the proximal facies of the Agüero alluvial fan. The sedimentary evolution of this fan was directly related to the structural development of the South Pyrenean frontal thrust in the External Sierras (Arenas et al., 2001). In the central portion of this range, contractional deformation dominated at least until the end of the early Miocene (Millán Garrido et al., 2000; Gibson et al., 2007; Whitchurch et al., 2011). The fan apex was adjacent to the source area, which was located on the southern side of the External Sierras (Hogan and Burbank, 1996; Arenas et al., 2001) (Fig. 2). The sedimentary response to the movement of such thrust sheets can be considered instantaneous on geological time scales. In contrast, magnetostratigraphic dating of the T4/T5 boundary in the Huesca system was performed in the distal facies (sections 1 and 2), whose sediment source area extended from the Marginal Sierras (in the southern portion of the South Pyrenean Central Unit) to the Axial Zone and may have included a transfer subsystem (sensu Castelltort and Van Den Driessche, 2003) or a transfer zone (sensu Romans et al., 2016) of unknown length at ca. 21.5 Ma. The sedimentary response of the Huesca system to an uplift in the drainage area may have been delayed with respect to the uplift time, even if the uplift was synchronous with the structural development of the External Sierras. Notably, fission track ages (ranging between $19.4 \pm 2.7$ and $20.9 \pm 2.0$ ) that were reported from the southern portion of the Axial Zone by Labaume et al. (2016, and references therein) are consistent with the uplift of the catchment area in relation to the T4/T5 boundary.

The T5/T6 boundary has only been dated in the central areas of the basin (the Sierra de Alcubierre, Montes de Castejón and Bardenas Reales). No evidence exists of deposits that correspond to unit T6 at the central basin's Pyrenean margin. However, this unit has been identified in the western Pyrenean (Angulo et al., 2000) and western Iberian margins of the basin (Pérez, 1989), and the T5/T6 boundary is an unconformity in both areas. Moreover, the change from evaporite deposition to carbonate lacustrine sedimentation in the basin's centre reveals a significant climatic change toward more humid conditions at approximately 16Ma (Arenas et al., 1997). Concerning the timing of the uplift of the catchment area, Morris et al. (1998) measured a cooling age of $16 \pm 1.5 \mathrm{Ma}$ by using apatite fission tracks in the Bielsa massif, which is consistent with the age of the T5/T6 boundary in the Ebro basin.

Surface, relief and climatic conditions in catchment areas determine the total volume of sediment that is contributed to the corre- sponding sedimentary systems and their architecture, i.e., a large distributary fan vs. a small alluvial fan. The climatic contrast that currently occurs between wetter conditions at the Pyrenean Range and drier conditions at the Iberian Range was probably similar during the Miocene. In fact, such a climatic contrast between the Pyrenean and Iberian catchment areas was suggested to explain the differences in Miocene lacustrine facies between the northern and southern deposits in the central lake of the Ebro basin (Arenas and Pardo, 1999). However, the delay of approximately $0.3 \mathrm{Ma}$ between the Huesca fluvial system and the Los Fayos fan that was estimated for the T6/T7 boundary does not seem consistent with differences in climatic conditions but rather with distinct tectonic contexts.

Despite the lack of stratigraphic evidence for contractive tectonic activity after the deposition of unit T5 along the Pyrenean margin of the central sector of the Ebro basin (no younger units crop out in this area), Arenas (1993) and Arenas and Pardo (2000) postulated that a later Pyrenean uplift occurred in relation to the T6/T7 boundary based on the characteristics of this boundary in section 4 (see Fig. 2 for the location of this section, alongside Fig. 4). In the Sierra de Alcubierre area, the deposition of unit T7 represents the sudden invasion of the central lacustrine area with detrital sediments (mudstones and sandstones) from the Huesca fluvial system. These sediments are rich in biotite grains that originated in the Axial Zone (Arenas, 1993).

The Iberian range mostly became a passive margin in the Ebro basin after the deposition of unit T5; this feature is shown by the progressive southward migration of depocentres and the general onlap geometry of units T6 and T7 toward the Iberian range (Pérez et al., 1994; Muñoz et al., 2002; Pardo et al., 2004). However, the T6/T7 boundary in the Los Fayos fan is an angular unconformity that formed from the activity of a blind thrust (Fig. 4; the Peñas Negras thrust, San Román, 1994), which was that is linked to the eastern ramp of the Cameros thrust (Fig. 2). The Cameros thrust is the northernmost tectonic structure of the Iberian Range that, as with its counterpart in the Sierra de Cantabria (along the western Pyrenean margin), was active in the wester sector of the Ebro basin until the beginning of the deposition of unit T8, which likely occurred during the late middle Miocene to late Miocene (Muñoz, 1992; Muñoz-Jiménez and Casas-Sainz, 1997; Muñoz et al., 2002). Together, this information suggests that the diachrony that was recorded by the T6/T7 boundary between the Ebro basin sediment-source areas in the Pyrenean Range and the Iberian Range farther west may reflect a concrete case of the general delay in the east to west transmission of stresses from the collision between the Iberian and Eurasian plates which led to the development of both ranges.

In summary, the limited degree of diachroneity for TSU boundaries (conformable boundaries) in a basin can be caused by the above-mentioned depositional and palaeogeographic factors and errors that are inherent in the correlation process (i.e., photogeological and field correlations). Despite all these factors acting together, the results for the Ebro basin support the correlation of conformable boundaries between genetic stratigraphic units with an accuracy better than a few tens of thousands to hundreds of thousands of years (between 0.2 and $0.3 \mathrm{Ma}$ ).

\section{Conclusions}

Previously acquired and new magnetostratigraphic data from several successions in the Miocene of the Ebro basin were analysed in this work. The results demonstrated that the degree of diachroneity of the boundaries between tecto-sedimentary units that were identified via tecto-sedimentary analysis was relatively small 
where these boundaries were conformities. These boundaries were dated as follows:

- The age of the T4/T5 boundary was estimated to be $21.30 \mathrm{Ma}$ in the basin centre, and $21.50 \mathrm{Ma}$ in the northern basin margin, which represents a $0.2 \mathrm{ka}$ difference.

- The age of the T5/T6 boundary in three central areas of the basin was estimated to be $16.34 \mathrm{Ma}, 16.10 \mathrm{Ma}$ and $16.06 \mathrm{Ma}$, with a maximum difference of $0.28 \mathrm{ka}$.

- The age of the T6/T7 boundary was estimated to be $14.44 \mathrm{Ma}$ in the basin centre and $14.16 \mathrm{Ma}$ in the southern basin margin, which represents a $0.28 \mathrm{ka}$ difference.

The limited degree of diachroneity that was associated with this type of boundary throughout the studied sector of the Ebro basin could be explained by the various depositional and palaeogeographic features in the basin and catchment areas and potential methodological inaccuracies from the correlation process, in particular, between areas that were not connected by continuous outcrops.

In this study, magnetostratigraphy proved to be a powerful tool for age-dating fluvial and lacustrine deposits across a continental basin (Ebro basin, Spain) and assessing the temporal character of the regional stratigraphic boundaries (in this case, previously recognised tecto-sedimentary units). This work provided empirical evidence that the bounding surfaces between genetic stratigraphic units within a basin have low-diachrony where they are conformable (i.e., far from basin margins and associated unconformities).

The use of tecto-sedimentary unit boundaries as correlation surfaces, where they are conformable, can be relevant for correlation, in particular in large basins or in basins that lack chronological data (biochronological and geochronological).

\section{Uncited reference}

Payton, 1977

\section{Acknowledgements}

This work was funded by projects PB97-0882-C03-02 and CGL2013-43867-P of the DGES (Ministry of Technology and Science and Ministry of Economy and Competitiveness of Spain) and forms a component of the objectives of the group "Continental sedimentary basin analysis" of the Aragón Government-University of Zaragoza, Spain.

The reviewers A.J. Mumphy and an anonymous reviewer provided very constructive comments and criticism to improve an early version of this manuscript.

\section{References}

Abels, H.A., Abdul Aziz, H., Krijgsman, W., Smeets, S.J.B., Hilgen, F.J., 2010. Long-period eccentricity control on sedimentary sequences in the continental Madrid Basin (middle Miocene, Spain). Earth Planet. Sci. Lett. 289, 220-231.

Agustí, J., Cabrera, L., Garcés, M., Krijgsman, W., Oms, O., Parés, J.M., 2001. A calibrated mammal scale for the Neogene of Western Europe. State of the art. Earth-Science Rev. 52, 247-260. https://doi.org/10.1016/S0012-8252(00)00025-8.

Agustí, J., Pérez-Rivarés, F.J., Cabrera, L., Garcés, M., Pardo, G., Arenas, C., 2011. The Ramblian-Aragonian boundary and its significance for the European Neogene continental chronology. Contributions from the Ebro Basin record (NE Spain). Geobios 44, 121-134. https://doi.org/10.1016/j.geobios.2011.01.001.

Allen, P.A., Densmore, A.L., 2000. Sediment flux from an uplifting fault block. Basin Res. $12,367-380$.
Allen, P.A., Armitage, J.J., Carter, A., Duller, R.A., Michael, N.A., Sinclair, H.D., Whitchurch, A.L., Whittaker, A.C., 2013. The Qs problem: sediment volumetric balance of proximal foreland basin systems. Sedimentology 60, 102-130.

Alonso-Zarza, A.M., Calvo, J.P., García del Cura, M.A., 1990. Litoestratigrafía y evolución paleogeográfica del Mioceno del borde NE de la Cuenca de Madrid (Prov. Guadalajara). Estud. Geol. 46, 415-432.

Angulo, A., Bracero, C., Muñoz, A., 2000. Caracterización de las Unidades Tectosedimentarias de la Comarca de la Bureba (Burgos, España) y su correlación con las cuencas terciarias del Ebro y Duero. Geotemas. 1, 19-23.

Antunes, M.T., Calvo, J.P., Hoyos, M., Morales, J., Ordóñez, S., Pais, J., Sesé, C., 1987. Ensayo de Correlacion entre el Neogeno de las áreas de Madrid y Lisboa (Cuencas Alta y Baja del Rio Tajo). Comun. Serv. Geol. Portugal. 73 (fasc. 112), 85-102.

Arche, A., Evans, G., Clavell, E., 2010. Some considerations on the initiation of the present SE Ebro river drainage system: post- or pre-Messinian?. J. Iber. Geol. 36, 73-85.

Arenas, C., 1993. Sedimentología y paleogeografía del Terciario del margen pirenaico y sector central de la Cuenca del Ebro (zona aragonesa occidental). In: PhD Thesis. Universidad de Zaragoza, (858 p.).

Arenas, C., Pardo, G., 1999. Latest Oligocene-Late Miocene lacustrine system of the north-central part of the Ebro Basin (Spain): sedimentary facies model and palaeogeographic synthesis. Palaeogeogr. Palaeoclimatol. Palaeoecol. 151, 127-148.

Arenas, C., Pardo, G., 2000. Neogene lacustrine deposits of the North-central Ebro Basin, Northeastern Spain. In: Gierlowski-Kordesch, E.H., Kelts, K.R. (Eds.), Lake Basins Through Space and Time. AAPG Studies in Geology. pp. 395-406.

Arenas, C., Casanova, J., Pardo, G., 1997. Stable-isotope characterization of the Miocene lacustrine systems of Los Monegros (Ebro basin, Spain): palaeogeographic and palaeoclimatic implications. Palaeogeogr. Palaeoclimatol. Palaeoecol. 128, 133-155.

Arenas, C., Millán, H., Pardo, G., Pocoví, A., 2001. Ebro Basin continental sedimentation associated with late compressional Pyrenean tectonics (north-eastern Iberia): controls on basin margin fans and fluvial systems. Basin Res. 13, 65-89.

Astibia, H., 1986. Los macromamiferos del Mioceno medio de Tarazona de Aragón (depresión del Ebro). In: PhD Thesis. Universidad del País Vasco, (265p.).

Astibia, H., 1987. Los macromamiferos del Mioceno medio de Tarazona de Aragón (Depresión del Ebro, provincia de Zaragoza). Paleontología i evolució. 21, 11-42.

Azanza, B., 1986. Estudio geológico y paleontológico del Mioceno del sector oeste de la comarca de Borja. Cuadernos de Estudios Borjanos. 17-18, 63-126.

Azanza, B., Canudo, J.I., Cuenca, G., 1988. Nuevos datos bioestratigráficos del Terciario continental de la Cuenca del Ebro (sector centro-occidental). In: II Congreso Geológico de España, comunicaciones. 1. pp. 261-264.

1987. Atlas of seismic stratigraphy. In: Bally, A.W. (Ed.), AAPG Studies in Geology. 27. vol. 1 , (125 p.).

Barnolas, A., Payros, A., Samsó, J.M., Serra-Kiel, J., Tosquella, J., 2004. La Cuenca Surpirenaica desde el Ilerdiense medio al Priaboniense. In: Vera, J. (Ed.), Geología de España. SGE-IGME, Madrid, pp. 313-320.

Calvo, J.P., Ordóñez, S., García del Cura, M.A., Hoyos, M., Alonso-Zarza, A.M., Sanz, E., Rodríguez Aranda, J.P., 1989. Sedimentologia de los complejos lacustres miocenos de la Cuenca de Madrid. Acta Geol. Hisp. 24, 281-298.

Cámara, P., Klimowitz, J., 1985. Interpretación geodinámica de de la vertiente centro-occidental surpirenaica (Cuencas de Jaca-Tremp). Estud. Geol. 41, 391-404.

Capote, R., Muñoz, J.A., Simón, J.L., Liesa, C.L., Arlegui, L.E., 2002. Alpine tectonics I: the Alpine system north of the Betic Cordillera. In: Gibbons, W., Moreno, T. (Eds.), The Geology of Spain. The Geological Society, pp. 367-400.

Castelltort, S., Van Den Driessche, J., 2003. How plausible are high-frequency sediment supply-driven cycles in the stratigraphic record?. Sediment. Geol. 157, 3-13.

Catuneanu, O., 2006. Principles of Sequence Stratigraphy. Elsevier, (375 p.).

Catuneanu, O., Elango, H., 2001. Tectonic control on fluvial styles: the Balfour Formation of the Karoo Basin, South Africa. Sediment. Geol. 140, 291-313.

Catuneanu, O., Abreu, V., Bhattacharya, J.P., Blum, M.D., Dalrymple, R.W., Eriksson, P.G., Fielding, C.R., Fisher, W.L., Galloway, W.E., Gibling, M.R., Giles, K.A., Holbrook, J.M., Jordan, R., Kendall, C.G.St.C., Macurda, B., Martinsen, O.J., Miall, A.D., Neal, J.E., Nummedal, D., Pomar, L., Posamentier, H.W., Pratt, B.R., Sarg, J.F., Shanley, K.W., Steel, R.J., Strasser, A., Tucker, M.E., Winker, C., 2009. Towards the standardization of sequence stratigraphy. Earth Sci. Rev. 92, 1-33. 
Catuneanu, O., Galloway, W.E., Kendall, C.G.St.C., Miall, A.D., Posamentier, H.W., Strasser, A., Tucker, M.E., 2011. Sequence stratigraphy: methodology and nomenclature. Newsl. Stratigr. 44 (3), 173-245.

Choukroune, P., 1992. Tectonic evolution of the Pyrenees. Annu. Rev. Earth Planet. Sci. 20, 143-1258. https://doi.org/10.1146/annurev.earth.20.1.143.

Costa, E., Garcés, M., López-Blanco, M., Beamud, E., Gómez-Paccard, M., Larrasoaña, J.C., 2010. Closing and continentalization of the South Pyrenean foreland basin (NE): magnetochronological constraints. Basin Res. 22, 904-917.

Cuenca, G., Canudo, J.I., Laplana, C., Andres, J.A., 1992. Bio y cronoestratigrafía con mamíferos en la Cuenca Terciaria de Ebro: ensayo de síntesis. Acta Geol. Hisp. 27, 127-143.

Daams, R., Freudenthal, M., 1981. Aragonian: the stage concept versus Neogene mammal zones. Scr. Geol. 62, 1-18.

Daams, R., Freudenthal, M., van der Weerd, A., 1977. Aragonian, a new stage for continental deposits of Miocene age. Newsl. Stratigr. 6 (1), 42-55.

Daams, R., Van der Meulen, A.J., Sierra, Alvarez, M. de los, A., Peláez-Campomanes, P., Calvo, J.P., Alonso Zarza, M.A., Krijgsman, W., 1999. Stratigraphy and sedimentology of the Aragonian (Early to Middle Miocene) in its type area (North-Central Spain). Newsl. Stratigr. 37, 103-139.

Delfaud, J., 1972. Application de l'analyse séquentielle à l'exploration lithostratigraphique d'un bassin sédimentaire. L'example du Jurassique et du Crétacé inférieur de l'Aquitaine. Mem. BRGM 77, 593-611.

Delfaud, J., 1974. Typologie scalaire des séquences sédimentaires en fonction du milieu de dépôt. Bull. Soc. Geol. Fr. (6), 643-650.

Densmore, A.L., Allen, P.A., Simpson, G.C.F., 2007. Development and response of a coupled catchment fan system under changing tectonic and climatic forcing. J. Geophys. Res. Earth Surf. 112, F01002.

Domingo, M.S., Alberdi, M.T., Azanza, B., 2007. A new quantitative biochronological ordination for the Upper Neogene mammalian localities of Spain. Palaeogeogr. Palaeoclimatol. Palaeoecol. 255, 361-376.

Embry, A.F., 2009. Practical sequence stratigraphy. Can. Soc. Petrol. Geologists81 p. Online at www.cspg.org.

Ezquerro, L., 2017. El sector norte de la cuenca neógena de Teruel: tectónica, clima y sedimentación. In: PhD Thesis. Universidad de Zaragoza, (494p.).

Fanti, F., Catuneanu, O., 2010. Fluvial sequence stratigraphy: the Wapiti Formation, west-central Alberta, Canada. J. Sediment. Res. 80 (4), 320-338.

Galloway, W.E., 1989. Genetic stratigraphic sequences in basin analysis, I. Architecture and genesis of flooding-surface bounded depositional units. AAPG Bull. 73, 125-142.

Garcés, M., Krijgsman, W., Agustí, J., 2001. Chronostratigraphic framework and evolution of the Fortuna basin (Eastern Betics) since the Late Miocene. Basin Res. 13 (2), 199-216.

García-Castellanos, D., Vergés, J., Gaspar-Escribano, J., Cloetingh, S., 2003. Interplay between tectonics, climate and fluvial transport during the Cenozoic evolution of the Ebro Basin (NE Iberia). J. Geophys. Res. 108, 2347. https://doi.org/10.1029/ 2002JB002073.B7.

Garrido, A., Villena, J., 1977. Evolución vertical y paleogeográfica del Trías germánico de España. Cuadernos de Geología ibérica. 4, 37-56.

Garrido-Megías, A., 1973. Estudio geológico y relación entre tectónica y sedimentación del Secundario y Terciario de la vertiente meridional pirenaica en su zona central (provincias de Huesca y Lérida). In: PhD Thesis. Universidad de Granada, (395 p.).

Gibson, M., Sinclair, H.D., Lynn, G.J., Stuart, F.M., 2007. Late- to post-orogenic exhumation of the Central Pyrenees revealed through combined thermochronological data and modelling. Basin Res. 19, 323-334.

González, A., 1989. Análisis tectosedimentario del Terciario del borde SE de la Depresión del Ebro (sector bajoaragonés) y cubetas ibéricas marginales. In: PhD Thesis. Universidad de Zaragoza, (507 p.).

González, A., Pardo, G., Villena, J., 1988. El análisis tectosedimentario como instrumento de correlación entre cuencas. II Congreso Geológico de España, Simposios. 175-184.

Gradstein, F.M., Ogg, J.G., Schmitz, M.D., Ogg, G.M. (Eds.), 2012. The Geologic Time Scale 2012. Elsevier, (1144 p.).

Guimerà, J., 2004. Cadenas con cobertera: las cadenas Ibérica y Costera Catalana. In: Vera, J.A. (Ed.), Geología de España. Soc. Geol. España-IGME, pp. 602-617.

Hirst, J.P.P., Nichols, G.J., 1986. Thrust tectonic controls on the Miocene distribution patterns, Southern Pyrenees. In: Allen, P.A., Homewood, P. (Eds.), Foreland Basins. IAS Spec. Publ.. vol. 8, pp. 247-258.

Hogan, P.J., Burbank, D.W., 1996. Evolution of the Jaca piggyback basin and emergence of the External Sierras, Southern Pyrenees. In: Friend, P.F., Dabrio, C.J. (Eds.), Tertiary Basins of Spain: The Stratigraphic Record of Crustal Kinematics. Cambridge University Press, Cambridge, pp. 153-160.
IGME, 1975. Mapa Metalogenético de España E. 1:200.000, $1^{\text {a }}$ Edición, n 32, Zaragoza. Instituto Geológico y Minero de España. Serv. Public. Min. Industria. Hoja y Memoria, Madrid, (21 p.).

Johnson, J.G., Murphy, M.A., 1984. Time-rock model for Siluro-Devonian continental shelf, western United States. Geol. Soc. Am. Bull. 95, 1349-1359.

Kirschvink, J.L., 1980. The least-squares line and plane and the analysys of paleomagnetic data. Geophys. J. R. Astron. Soc. 62, 699-718.

Kodama, K.P., Hinnov, L.A., 2014. Rock magnetic cyclostratigraphy. In: Wiley-Blackwell Fast-Track Monograph. New Analytical Methods in Earth and Environmental Science Series. pp. 1-176.

Krijgsman, W., Garcés, M., Langereis, C.G., Daams, R., Van Dam, J., Van der Meulen, A.J., Cabrera, L., 1996. A new chronology for the middle to late Miocene continental record in Spain. Earth Planet. Sci. Lett. 142 (3-4), 367-380.

Labaume, P., Meresse, F., Jolivet, M., Teixell, A., 2016. Exhumation sequence of the basement thrust units in the west-central Pyrenees. Constraints from apatite fission track analysis. Geogaceta 60, 11-14

Larrasoaña, J.C., Murelaga, X., Garcés, M., 2006. Magnetobiochronology of Lower Miocene (Ramblian) continental sediments from the Tudela Formation (western Ebro basin, Spain). Earth Planet. Sci. Lett. 243, 409-423.

López Olmedo, F., Díaz de Neira, A., Martín Serrano, A., Calvo, J.P., Morales, J., Peláez-Campomanes, P., 2004. Unidades estratigráficas en el registro sedimentario neógeno del sector occidental de la Cuenca del Madrid. Rev. Soc. Geol. Esp. 17, 87-101.

Luzón, A., 2001. Análisis tectosedimentario de los materiales terciarios continentales de sector central de la Cuenca del Ebro (provincias de Huesca y Zaragoza). In: PhD Thesis. Universidad de Zaragoza, (465 p.).

Luzón, A., 2005. Oligocene-Miocene alluvial sedimentation in the northern Ebro Basin, NE Spain: tectonic control and palaeogeographical evolution. Sediment. Geol. 177, 19-39.

Martínez del Olmo, W., Megías, A.G., Abeger, J.A., 1986. Nuevos datos sobre la Cuenca del Mar Menor. Actas del IX Congreso Nacional de Sedimentología. II 652-665.

McFadden, P.L., McElhinny, M.W., 1990. Classification of the reversal test in paleomagnetism. Geophys. J. Int. 103, 725-729. https://doi.org/10.1111/j.1365-246X.1990. tb05683.x.

Mediavilla, R., Dabrio, C.J., 1988. Controles sedimentarios neógenos en la Depresión del Duero (Sector Central). Rev. Soc. Geol. Esp. 1, 187-198.

Mediavilla, R., Dabrlo, C.J., Martín-Serrano, A., Santisteban, J.I., 1996. Lacustrine Neogene systems of the Duero Basin: evolution and Controls. In: Friend, P.F., Dabrio, C.J. (Eds.), Tertiary Basins of Spain: The Stratigraphic Record of Crustal Kinematics. Cambridge University Press, Cambridge, pp. 228-236.

Megías, A.G., 1982. Introducción al análisis tectosedimentario: aplicación al estudio dinámico de cuencas. Actas del V Congreso Latinoamericano de Geología (Argentina) 385-402.

Mein, P., 1975. Résultats du groupe de travail des vertébrés: biozonation du Néogène méditerranéen à partir des mammifères. In: Senes, J. (Ed.), Report on Activity of the Regional Committee on Mediterranean Neogene Stratigraphy (RCMNS). Working Groups, Bratislava, pp. 77-81.

van der Meulen, A.J., García-Paredes, I., Álvarez-Sierra, , van den Hoek Ostende, L.W. Hordijk, K., Oliver, A., López-Guerrero, P., Hernández-Ballarín, V., Peláez-Campomanes, P., 2011. Biostratigraphy or biochronology? Lessons from the Early and Middle Miocene small Mammal Events in Europe. Geobios 44, 309-321.

Miall, A.D., 1995. Whither stratigraphy?. Sediment. Geol. 100, 5-20.

Miall, A.D., 2010. The Geology of Stratigraphic Sequences, second edition Springer-Verlag, Berlin, (522 p.).

Miall, A.D., 2016. The valuation of unconformities. Earth Sci. Rev. 163, 22-71.

Millán Garrido, H., Pueyo Morer, E.L., Aurell Cardona, M., Aguado Luzón, A., Oliva Urcia, B., Martínez-Peña, M.B., Pocoví Juan, A., 2000. Actividad tectónica registrada en los depósitos terciarios del frente meridional del Pirineo central. Rev. Soc. Geol. Esp. 13, 279-300.

Mitchum, R.M., Vail, P.R., Thompson, S., 1977. Seismic stratigraphy and global changes of sea level, part 2: the depositional sequence as a Basic Unit for stratigraphic analysis. Seismic stratigraphy applications to hydrocarbon exploration. Am. Ass. Petrol. Geol. Memoir 26, 53-62.

Montes, M., Beamud, E., Garcés, M., Calvo, J.P., 2006. Magnetocronología de las unidades Inferior e Intermedia del Mioceno de la Cuenca de Madrid. Rev. Soc. Geol. Esp. 19 281-298.

Morris, R.G., Sinclair, H.D., Yelland, A.J., 1998. Exhumation of the Pyrenean orogen: implications for sediment discharge. Basin Res. 10, 69-85.

Muñoz, A., 1992. Análisis tectosedimentario del Terciario del sector occidental de la Cuenca del Ebro (Comunidad de La Rioja). In: PhD Thesis. vol. 15, Universidad de Zaragoza. Publicaciones del Instituto de Estudios Riojanos, Ciencias de la Tierra, (347 p.).

Muñoz, A., Arenas, C., González, A., Luzón, A., Pardo, G., Pérez, A., Villena, J., 2002. Ebro basin (northeastern Spain). In: Gibbons, W. 
Moreno, T. (Eds.), The Geology of Spain. The Geological Society, Londres, pp. 301-309.

Muñoz-Jiménez, A., Casas-Sainz, A.M., 1997. The Rioja Trough (N Spain): tectosedimentary evolution of a symmetric foreland basin. Basin Res. 9, 65-85.

Murelaga, X., Pérez-Rivarés, F.J., Vázquez-Urbez, M., Zuluaga, M.C., 2008. Nuevos datos bioestratigráficos y paleoecológicos del Mioceno medio (Aragoniense) del área de Tarazona de Aragón (Cuenca del Ebro, provincia de Zaragoza, España). Ameghiniana 45, 393-406.

Odin, G.S., Cuenca, G., Canudo, J.L., Cosca, M., Lago, M., 1997. Biostratigraphy and geochronology of a Miocene continental volcaniclastic layer from the Ebro basin, Spain. In: Montanary, A., Odin, G.S., Coccioni, R. (Eds.), Miocene Stratigraphy: An Integrated Approach. Developments in Palaeontology and Stratigraphy. vol. 15, Elsevier, pp. 297-310

Oliva-Urcia, B., Beamud, E., Garcés, M., Arenas, C., Soto, R., Pueyo, E.L., Pardo, G., 2016. New magnetostratigraphic dating of the Palaeogene syntectonic sediments of the west-central Pyrenees: tectonostratigraphic implications. In: Pueyo, E.L., Cifelli, F., Sussman, A.J., Oliva-Urcia, B. (Eds.), Palaeomagnetism in Fold and Thrust Belts: New Perspectives. vol. 45, The Geological Society, London, Special Publications, pp. 107-128. https://doi.org/10.1144/SP425.5.

Opdike, N.D., Channell, J.E.T., 1996. Magnetic Stratigraphy. International Geophisics Series. vol. 64, Academic Press, San Diego, (346 p.)

Pardo, G., Villena, J., González, A., 1989. Contribución a los conceptos y a la aplicación del análisis tectosedimentario. Rupturas y unidades tectosedimentarias como fundamento de correlaciones estratigráficas. Rev. Soc. Geol. Esp. 2, 199-221.

Pardo, G., Arenas, C., González, A., Luzón, A., Muñoz, A., Pérez, A., Pérez-Rivarés, F.J., Vázquez-Urbez, M., Villena, J., 2004. La Cuenca del Ebro. In: Vera, J.A. (Ed.), Geología de España. SGE-IGME, Madrid, pp. 533-543.

Payton, C.E. (Ed.), 1977. Seismic Stratigraphy-Applications to Hydrocarbon Exploration. American Association of Petroleum Geologists, Memoir, 26. (516 p.).

Pérez, A., 1989. Estratigrafía y sedimentología del Terciario del borde meridional de la Depresión del Ebro (sector Riojano-Aragonés) y cubetas de Muniesa y Montalbán. In: PhD Thesis. Universidad de Zaragoza, (525 p.).

Pérez Rivarés, F.J., 2016. Estudio magnetoestratigráfico del Mioceno del sector central de la Cuenca del Ebro: Cronología, correlación y análisis de la ciclicidad sedimentaria. In: $\mathrm{PhD}$ Thesis. Universidad de Zaragoza, (281 p.).

Pérez, A., Muñoz, A., y Pardo, G., Villena, J., 1994. Lacustrine Neogene deposits of the Ebro Basin (southern margin), Northeastern Spain. In: Gierlowski-Kordesch, E., Kelts, K. (Eds.), Global Geological Record of the Lake Basins. World and Regional Geology. Cambridge University Press, Cambridge, pp. 325-330.

Pérez-Rivarés, F.J., Garcés, M., Arenas, C., y Pardo, G., 2002. Magnetocronología de la sucesión miocena de la Sierra de Alcubierre (sector central de la Cuenca del Ebro). Rev. Soc. Geol. Esp. 15, 217-231.

Pérez-Rivarés, F.J., Garcés, M., Arenas, C., y Pardo, G., 2004. Magnetostratigraphy of the Miocene continental deposits of the Montes de Castejón (central Ebro basin, Spain): geochronological and paleoenvironmental implications. Geol. Acta 2, 221-234.

Pla, S., Viseras, C., Soria, J.M., Arribas, A., 2007. El papel de la tectónica en la evolución sedimentaria en el sector occidental de la Cuenca de Guadix (Cordillera Bética, España). Geogaceta 43, 103-106.

Puigdefábregas, C., Souquet, P., 1986. Tecto-sedimentary cycles and depositional sequences of the Mesozoic and Tertiary from the Pyrenees. Tectonophysics 129, 173-203.

Ramón, M.J., Pueyo, E.L., Oliva-Urcia, B., Larrasoaña, J.C., 2017. Virtual directions in paleomagnetism: a global and rapid approach to evaluate the NRM components and their stability. Front. Earth Sci. 5 (8), 14 pp. https://doi.org/10.3389/feart.2017. 00008 .

Romans, B.W., Castelltort, S., Covault, J.A., Fildani, A., Walsh, J.P., 2016. Environmental signal propagation in sedimentary systems across timescales. Earth Sci. Rev. 153, 7-29.

San Román, J., 1994. Las aguas subterráneas en la cuenca del río Huecha (Zaragoza). Monografías del Centro de Estudios Borjanos. 9, (278 p.).

Santisteban, J.I., Martín-Serrano, A., Mediavilla, R., Molina, E., 1991. Introducción a la estratigrafía del Terciario del SO de la Cuenca del Duero. In: Blanco, J.A., Molina, E., Martín-Serrano, A. (Eds.), Alteraciones y paleoalteraciones en la morfología del oeste peninsular. Zócalo Hercínico y Cuencas Terciarias. Monogr. Soc. Española Geomorfol. vol. 6, pp. 185-198.

Santisteban, J.I., Mediavilla, R., Martín-Serrano, A., Dabrlo, C.J., 1996. The Duero Basin: a general overview. In: Friend, P.F., Dabrio, C.J.
(Eds.), Tertiary Basins of Spain: The Stratigraphic Record of Crustal Kinematics, Cambridge University Press, Cambridge, pp. 183-187.

Santisteban, J.I., Martín-Serrano, A., Mediavilla, R., Dabrlo, C.J., 1996. South-western Duero and Ciudad Rodrigo basins: infill and dissection of a Tertiary basin. In: Friend, P.F., Dabrio, C.J. (Eds.), Tertiary Basins of Spain: The Stratigraphic Record of Crustal Kinematics, Cambridge University Press, Cambridge, pp. 196-202.

Simo, A., 2004. El Cretácico superior de la Unidad Surpirenaica Central. In: Vera, J.A. (Ed.), Geología de España. SGE-IGME, Madrid, pp. 296-299.

Smith, A.G., 1996. Cenozoic latitudes, positions and topography of the Iberian Península. In: Friend, P.F., Dabrio, C.J. (Eds.), Tertiary Basins of Spain: The Stratigraphic Record of Crustal Kinematics. Cambridge University Press, Cambridge, pp. 6-8.

Soler, R., Martínez del Olmo, W., Megías, A.G., Abeger, J.A., 1986. Rasgos básicos del Neógeno del Mediterráneo español. Actas del IX Congreso Nacional de Sedimentología. II 705-718.

Teixell, A., 1998. Crustal structure and orogenic material budget in the west central Pyrenees. Tectonics 17, 395-406. https://doi.org/10.1029/98TC00561.

Teixell, A., García-Sansegundo, J., 1995. Estructura del sector central de la Cuenca de Jaca (Pirineos meridionales). Rev. Soc. Geol. Esp. 8, 215-228.

Urgeles, R., Camerlenghi, A., Garcia-Castellanos, D., De Mol, B., Garcés, M., Vergés, J. Haslam, I., Hardman, M., 2011. New constraints on the Messinian sealevel drawsown from 3D seismic data of the Ebro Margin, western Mediterranean. Basin Res. 23, $123-145$.

Vail, P.R., 1987. Seismic stratigraphy interpretation procedure. In: Bally, A.W. (Ed.), Atlas of Seismic Stratigraphy. Amer. Assoc. Petrol. Geol. Studies in Geol. vol. 27, pp. 1-10.

Valdés, G.G., Sesé, C., Astibia, H., 1986. Micromamíferos (Rodentia y Lagomorpha) del yacimiento del Mioceno medio de Tarazona de Aragón (Depresión del Ebro, Provincia de Zaragoza). Estud. Geol. 42, 41-49.

Van Dam, J.A., Abdul Aziz, H., Alvarez Sierra, , Hilgen, F.J., van den Hoek Ostende, L.W., Lourens, L.J., Mein, P., van der Meulen, A.J., Peláez-Campomanes, P., 2006. Long-period astronomical forcing of mammal turnover. Nature 443, 687-691, (Supplementary Notes: 1-10)

Van Wagoner, J.C., Mitchum, R.M., Posamentier, H.V., Vail, P.R., 1987. Key definitions of sequence stratigraphy. In: Bally, A.W. (Ed.), Atlas of seismic stratigraphy. AAPG Studies in Geology. 27. vol. 1, pp. 11-14.

Vázquez-Urbez, M., 2008. Caracterización y significado ambiental de depósitos tobáceos neógenos de la Cuenca del Ebro. Comparación con ambientes cuaternarios. In: $\mathrm{PhD}$ Thesis. University of Zaragoza, (476 p.).

Vázquez-Urbez, M., Arenas, C., Pardo, G., Pérez-Rivarés, J., 2013. The effect of drainage reorganization and climate on the sedimentologic evolution of intermontane lake systems: the final fill stage of the Tertiary Ebro Basin (Spain). J. Sediment. Res. 83, 562-590.

Villena, J., Gonzalez, A., Muñoz, A., Pardo, G., Pérez, A., 1992. Síntesis estratigráfica del Teciario del borde Sur de la Cuenca del Ebro: unidades genéticas. Acta Geol. Hisp. 27, 225-245.

Villena, J., Pardo, G., Pérez, A., Muñoz, A., Gonzalez, A., 1996. The Tertiary of the Iberian margin of the Ebro basin: sequence stratigraphy. In: Friend, P.F., Dabrio, C.J. (Eds.), Tertiary Basins of Spain: The Stratigraphic Record of Crustal Kinematics, Cambridge University Press, pp. 77-82.

Villena, J., Pardo, G., Pérez, A., Muñoz, A., Gonzalez, A., 1996. The Tertiary of the Iberian margin of the Ebro basin: paleogeography and tectonic control. In: Friend, P.F., Dabrio, C.J. (Eds.), Tertiary Basins of Spain: The Stratigraphic Record of Crustal Kinematics, Cambridge University Press, pp. 83-88.

Viseras, C., 1991. Estratigrafía y sedimentología del relleno aluvial de la Cuenca de Guadix (Cordilleras Béticas). In: PhD Thesis. Universidad de Granada, (327 p.).

Whitchurch, A.L., Carter, A., Sinclair, H.D., Duller, R.A., Whittaker, A.C., Allen, P.A., 2011. Sediment routing system evolution within a diachronously uplifting orogen: insights from detrital zircon thermochronological analyses from the south-central Pyrenees. Am. J. Sci. 311, 442-482. https://doi.org/10.2475/05.2011.03.

Wilgus, C.K., Hastings, B.S., Kendall, C.G.St.C., Posamentier, H.W., Ross, C.A., Van Wagoner, J.C. (Eds.), 1988. Sea Level Changes-An Integrated Approach. SEPM, Special Publication 42, Tulsa, Oklahoma, (407 p.).

Yuste, A., Luzón, A., Bauluz, B., 2004. Provenance of Oligo-Miocene alluvial and fluvia fans of the northern Ebro Basin (Spain): a XRD, petrographic and SEM study. Sediment. Geol. 172, 251-268.

Zijderveld, J.D.A., 1967. AC demagnetization of rocks: analysis of results. In: Collinson, D.W., Creer, K.M., Runcorn, S.K. (Eds.), Methods in Paleomagnetism. Elsevier, Amsterdam, pp. 254-286. 